\title{
Predmety používané pri výrobe textilu \\ z Hlinska - Nad Zbružovým. Analýza praslenov \\ a tkáčskych závaží na základe ich hmotnosti a rozmerov
}

\author{
Items used in the production of textiles \\ from Hlinsko - Nad Zbružovým. Analysis of spindle whorls \\ and loom weights based on their weight and dimensions
}

\author{
Jana Šofránková
}

\begin{abstract}
Abstrakt
Na lokalite Hlinsko v polohe Nad Zbružovým sa našlo 1236 nástrojov na výrobu textilu (Pavelčík 1983), ktoré doteraz neboli detailne spracované. Z predchádzajúcich zahraničných experimentálnych výskumov vyplýva, že hmotnost' a rozmery praslenov a tkáčskych závaží ovplyvňujú proces spracovania textilu ako aj jeho výsledný produkt. Ciel'om článku je analýza vybraných nástrojov na základe ich tvaru, rozmerov a hmotnosti. Príspevok sa d'alej zaoberá typom používaných vláken s ohl'adom na archeobotanické nálezy, prírodné podmienky, počet archeologických nálezov ako aj výskumom eneolitických lokalít z d'alších miest Európy. Podáva obraz o textilnej výrobe v lokalite Hlinsko a je zameraný nielen na podrobnosti o používaných typoch vláken, nití a tkanín, ale popisuje aj organizáciu a špecializáciu spoločnosti v mladšom praveku obecne.
\end{abstract}

\section{Kl'účové slová}

textilná výroba, praslen, tkáčske závažie, Morava

\begin{abstract}
One thousand two hundred thirty-six tools (Pavelčík 1983) connected with textile production were recovered on the site Hlinsko in the last century, the tools were not further analysed since then. Previously carried out experimental research abroad shows that the weight and the dimensions of the spindle whorls and loom weights affect the final products, yarn and fabric. The aim of the paper is to analyse selected tools based on their shape, dimensions, and weight. The article also deals with the type of fibres used regarding archaeobotanical finds, natural conditions, the number of archaeological finds as well as state of research at other Aeneolithic sites in Europe. It gives thus a comprehensive picture of the textile production at Hlinsko, with the aim not only to describe the tools themselves but to expound the organisation and specialisation of textile production during late prehistory in general.
\end{abstract}

\section{Key words}

textile production, spindle whorl, loom weight, Moravia 


\section{1. Úvod}

Hlinsko patrí medzi jednu z najviac preskúmaných eneolitických lokalít na Morave. Počas 26 (1962, 1968-1992, 2006, 2008) výskumných sezón na lokalite Hlinsko, v polohe Nad Zbružovým, sa našlo niekol'ko desiatok tisíc predmetov a 607 nálezových objektov (Šebela et al. 2007, 17, 49). Výskum pod vedením dr. Jiřího Pavelčíka prebiehal na danú dobu moderne, spolupracovali na ňom odborníci z rôznych prírodovedeckých odvetví. Pravidelne vychádzali správy o stave výskumu v rámci prehladov, ktoré J. Pavelčík doplňoval článkami venujúcimi sa keramike jednotlivých horizontov, ale aj terakotovým alebo kosteným predmetom, za primárny zdroj sa považujú podrobné nálezové správy.

Táto štúdia sa cielene venuje len istému segmentu týchto nálezov - predmetom používaných pri výrobe textilu. Textil je súhrnné označenie textilných surovín (vlákna, pradiva), polotovarov (priadze) a výrobkov (tkaniny, pleteniny, plsti a i.). Tento pojem sa často chybne zužuje len na tkaniny, alebo sa stotožňuje s termínom textília (ELKS 1995-II, 257). Pavelčík spomína dohromady 1236 nástrojov na výrobu textilu, pod čím rozumieme prasleny, tkáčske závažia, cievky, šidlá a ihly. Tým sa venoval v článku Drobné terakoty z Hlinska u Lipniku (Pavelčik 1983), väčšinovo sú ale podrobne popísané len v nálezových správach ${ }^{1}$. Pri praslenoch sa venuje primárne ich výzdobe a následne ich porovnáva s nálezmi z ostatných eneolitických lokalít na Morave. Poplatne vtedajšiemu stavu bádania pri tom neuvádzal ich hmotnost alebo ich presnejšie rozmery, ktoré sa medzičasom ukázali ako podstatné pre ich d’alšiu interpretáciu. Pri tkáčskych závažiach postupuje podobne, uvádza len obecne ich hmotnostné rozmedzie, uvažuje pritom aj o iných možných spôsoboch využitia závaží, ktoré postupne vy- lučuje. Jeho článok je napriek svojim dobovým limitom jedným z najdôležitejších zdrojov o textilnej výrobe $\mathrm{z}$ obdobia eneolitu na našom území z osemdesiatych rokov. ${ }^{2}$

Práve chýbajúca hmotnost’ a $\mathrm{v}$ niektorých d’alších prípadoch aj presnejších rozmerov bola dôvodom pre nové spracovanie týchto nálezov. Z novších experimentálne zameraných výskumov vieme, že lahšie a vyššie prasleny s menším priemerom sa otáčajú rýchlejšie a sú teda vhodnejšie k pradeniu kratších vláken, vláken živočíšneho pôvodu. Naopak, prasleny s väčším priemerom sú vhodnejšie $\mathrm{k}$ pradeniu dlhších vláken, prípadne k súkaniu (Gleba - Harris 2019, 2341).

Cielom práce je popis a interpretácia textilných nástrojov z Hlinska, na základe najčastejšie sa vyskytujúcich typov praslenov a závaží, ako aj určenie používaných vláken a charakteristika stupňa špecializácie textilnej výroby. Článok sa konkrétnejšie zameriava na pôvod vláken používaných pri pradení a to na základe nepriamych dôkazov, teda tvaru predmetov, klímy, osteologických zvyškov, archeobotanických dokladov. Overovaná je i teória, že práve výskyt kónických praslenov - spoločne s rozšírením pradenia živočíšnych vláken - sa považuje za isté špecifikum typické v lokalitách obsadených badenskou kultúrou a ktoré sa v posledných rokoch spája s procesom tzv. badenizácie (Grabundžija 2018, 2021). Okrem morfometrickej analýzy rozmerov a tvaru, ako aj následnej diskusie o určení používaného materiálu k výrobe nití, práca posudzuje i organizáciu a stupeň výroby na sídlisku, kde vychádza najmä z množstva a uloženia dochovaných textilných nástrojov. Spracovaná je i skupina vel'mi dobre dochovaných tkáčskych závaží. Nasimulovaním rôznych podmienok u jednotlivých skupín závaží, ktoré sa líšia hmotnostou je vyhodnotený najvhodnejší počet uviazaných nití ako i počet nití na centimeter. 

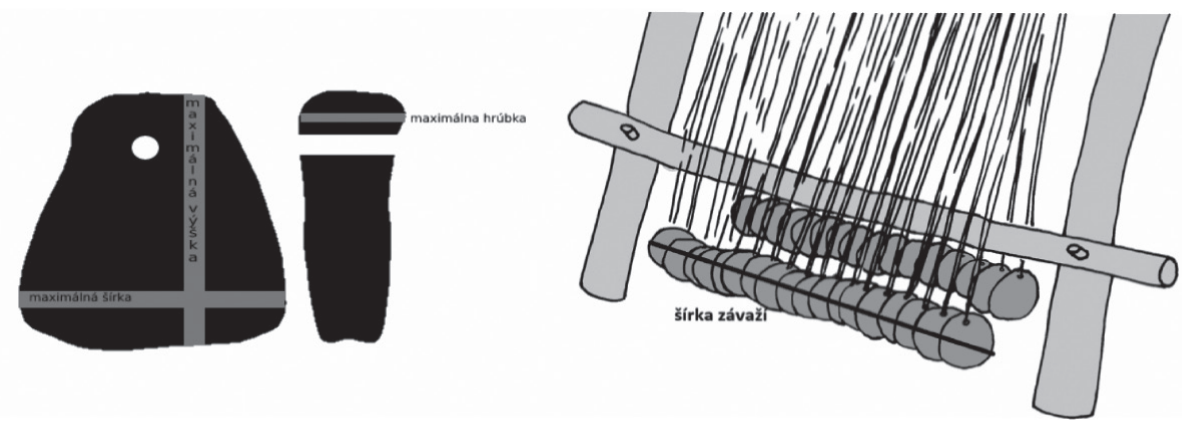

Obr. 1. Rozmery tkáčskeho závažia a zobrazenie šírky celej rady závaží.

Fig. 1. Dimensions of the loom weight and display of the width of the whole range of weights

\section{Metodológia}

So vznikom Centre for Textile Research (CTR) v Kodani ${ }^{4}$, sa v priebehu posledných dvoch desatročí presunula pozornost̉ z katalogizovania predmetov na základe tvaru na ich funkčnost'. Vd’aka mnohým experimentom vykonaným v rámci CTR sa zistilo, že tvar a hmotnost̉ praslenov má podstatný vplyv na výsledný produkt, teda na nit. Pri pradení slúži praslen ako zotrvačník a pradenie prebieha na základe momentu zotrvačnosti, ktorý je priamo úmerný hmotnosti a druhej mocniny polomeru (konkrétny vzorec závisí na danom tvare praslenu). Na rýchlost̉ otáčania má vplyv priemer a výška praslenu - určuje takzvaný zákrut (Andersson Strand 2003, 25). Všeobecne platí, že tažšie prasleny sa používajú na pradenie hrubších nití a lahšie na pradenie jemnejších nití (je ale potrebné brat do úvahy aj prax osoby, ktorá pradie, typ vlákna apod.) (Barber 1991, 25; Gleba 2008, 103-106). Na základe hrúbky nite sa určí aké napnutie je potrebné pre upradenú nit. ${ }^{5}$ Ďalej nasleduje posledný krok, kedy hmotnosṫ tkáčskeho závažia vydelíme hmotnostou potrebnou $\mathrm{k}$ zataženiu jednej nite a tak nám vyjde počet nití potrebných na uviazanie na jedno tkáčske závažie. Súčet hrúbok jednotlivých závaží určuje šírku celej rady závaží a teda definuje šírku tkaniny (Obr. 1) (Mårtensson et al. 2009, 373). Vd’aka týmto parametrom je možné rekonštruovat textilnú výrobu i na miestach, kde neboli objavené žiadne zvyšky textilu a ostatné ako dekorácia, materiál, výška patria medzi také, ktoré nemajú vplyv na funkčnost́. Ide o vlastnosti, ktoré odrážajú vkus l’udí danej spoločnosti, poprípade trendy, ktoré sa preberali z iných oblastí. Na základe typológie závaží je možné sledovat distribúciu jednotlivých typov (napríklad v dobe bronzovej v egejskej oblasti boli oblúbené isté tvary na ostrovoch a v prímorských lokalitách na pevnine, iné naopak vo vnútrozemí) (Staničová 2017).

Pri spracovaní nástrojov na výrobu textilu som preto mala od začiatku jasne definovaný postup, ktorý vychádzal z upraveného návodu od CTR Manual for recording textile tools (Andersson Strand et al. 2011) ${ }^{6}$. Po dôkladnej úvahe som sa rozhodla analyzovat predmety z Hlinska, avšak nie všetky, ktoré boli k dispozícií. Zamerala som sa také kusy, ktoré boli nájdené v skupinách, ked’že sa dá predpokladat, že prinášajú najväčšiu výpovednú hodnotu, či už o type použitého vlákna upradenej nite alebo o vlastnostiach tkaniny. Pri každom praslene som sledovala priemer, výšku, priemer otvoru a prípadnú 


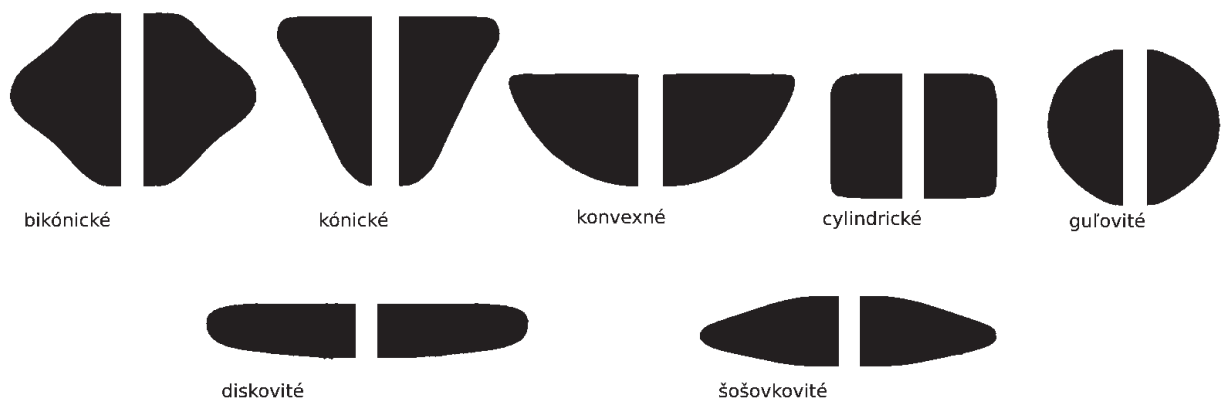

Obr. 2. Typy praslenov.

Fig. 2. Types of spindle whorls.

dekoráciu. Pri tkáčskych závažiach zase výšku, šírku podstavy, hrúbku, počet otvorov, priemer otvoru a pokial to bolo možné aj šírku vrchnej časti. Tá bola v mnohých prípadoch odpadnutá. V̌setky tieto údaje som vpisovala do databázy SQL, ktorú som si vybrala, pretože je najvhodnejšia $\mathrm{k}$ následnému zverejneniu na internete. Databáza bude dostupná online, bude v nej dostupných viac ako 2000 spracovaných nástrojov na výrobu textilu z obdobia neolitu a eneolitu z oblasti Moravy a juhozápadného Slovenska. Každý predmet má pridelené vlastné identifikačné číslo ako aj pôvodné prírastkové číslo, ktoré mu bolo pridelené v danom múzeu. V databáze sú uvedené aj d’alšie špecifiká ako materiál, dekorácia, umiestnenie, absolútna i relatívna chronológia, stav zachovania, úprava povrchu, kontext, a d’alšie. Takisto je tam stĺpec zachytávajúci dopočítanú váhu, pokial' je predmet zachovaný len fragmentárne, teda len jeho polovica, tretina, prípadne len štvrtina. V týchto prípadoch je hmotnost dopočítaná ${ }^{7}$, aby aj tieto predmety mohli byt zahrnuté do analýzy a následnej štatistiky.

Predmety som rozdelila podla typov a hmotnostných rozmedzí. Z manuálu CTR som prebrala obecnú typológiu (Obr. 2), kvôli kompatibilite s ostatnými databázami ${ }^{8}$. Následne boli vytvorené grafy zobrazujúce distribúciu predmetov na základe hmotnosti a priemeru. Z grafov bol zhodnotený typ pradenej nite ako aj predpokladaný surový materiál na výrobu vláken. Podobne sa analyzovali aj tkáčske závažia - na základe ich hmotnosti, rozmerov a typu.

Pri posudzovaní vlákna použitého k produkcii vychádzam najmä z prírodných podmienok v danom mieste, archeobotanických a osteologických zvyškov. V neposlednom rade vychádzam aj z posledných štúdií opisujúcich textilnú výrobu v Panónskej nížine (Grabundžija 2020; Grabundžija et al. 2021), ktoré sa venujú textilnej výrobe a rozoberajú možnost’ špecializovanej výroby ako aj používaniu živočíšnych vláken v období eneolitu.

\section{Výsledky analýzy praslenov a tkáčskych závaží}

\subsection{Prasleny}

Pavelčík vo svojom článku z roku 1983 vyhodnotil 870 praslenov, z nich som analyzovala 238 kusov. Popisná analýza nie úplne všetkých praslenov bola spôsobená hlavne obmedzenými časovými možnostami, ktoré som mala k dispo- 


\section{Typy praslenov, $\mathbf{N}=\mathbf{2 3 4}$}

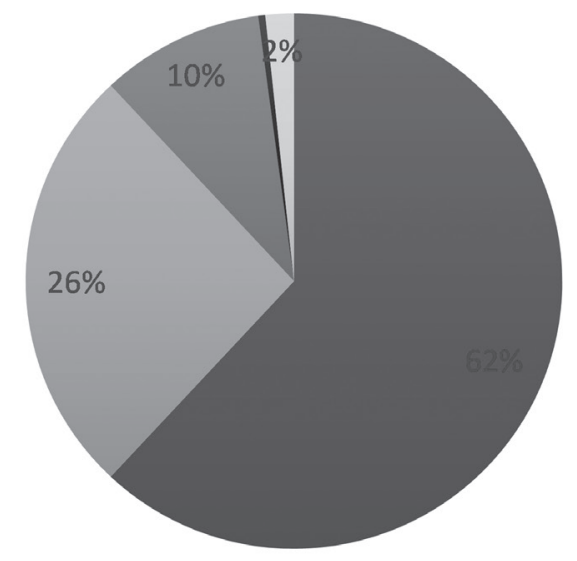

\section{घónické घ̌ošovkovité घ bikónické gul'ovité diskovité}

Graf 1. Percentuálne zastúpenie typov praslenov, $\mathrm{N}=234$.

Graph 1. Percentage of types of spindle whorls, $N=234$.

zícii. Nálezové správy som ale prešla všetky, a to práve s cielom nájst' vhodné skupiny predmetov na spracovanie. Z celkového počtu spracovaných praslenov je $20,1 \%$ vo fragmentárnom stave zachovania, avšak i napriek tomu, vd’aka dopočítaniu váhy je možné tieto prasleny použit pri výpočte mediánu a hmotnosti. Pri určovaní distribúcie praslenov na základe hmotnosti a priemeru bolo z celkového počtu odpočítaných 19 kusov - nemali zachovaný priemer. Všetky ale pochádzajú z objektov, kde boli nájdené v skupinách. Prasleny som zaradila do jednotlivých typov. Z Grafu 1 je zrejmé, že najviac bolo nájdených kónických praslenov (62 \%), hned' za nimi sú šošovkovité prasleny (26\%). Zastúpené sú aj ostatné tvary ako bikónické (10\%), diskovité (2\%), dokonca aj jeden gul'ovitý. Ked' ich porovnáme s neolitickými praslenmi z lokalít na juhozápadnom Slovensku, tak ide o posun v typológii - pre neolit sú totiž typickejšie bikónické prasleny, ktoré sú rozmerovo väčšie a hmotnostne tažšie (Staničová 2019).
Prasleny z Hlinska sú vyrobené z pálenej hliny. Farebne môžeme rozlíšit prasleny v odtieňoch svetlo a tmavo sivej až čiernej farby a prasleny oranžovo tehlové. Niektoré oranžové prasleny nesú známky ohorenia - jedna polovica je oranžová a druhá čierna (možno ide ale len o doklad nerovnomerného oxidačno-redukčného výpalu). Ostrivo v matrixe je viditelné zriedka a v malom množstve, najčastejšie na praslenoch sivých odtieňov. Vo vybranej vzorke som nenašla žiaden kus vyrobený z kameňa, kostí alebo iného materiálu.

Priemerná hmotnost' je 35,5 g, pre účely zhodnotenia textilnej výroby je ale viac vypovedajúci tzv. medián (teda stredná hodnota), ktorý je 34 g. Z Grafu 2, na ktorom je znázornená distribúcia praslenov na základe priemeru a hmotnosti, môžeme vyčítat, že typ praslenu neurčuje jeho hmotnost', všetky typy sú totiž zastúpené vo všetkých hmotnostných rozmedziach. Najviac praslenov má priemer medzi 40-50 mm a hmotnost' medzi 30-40 g, z čoho 


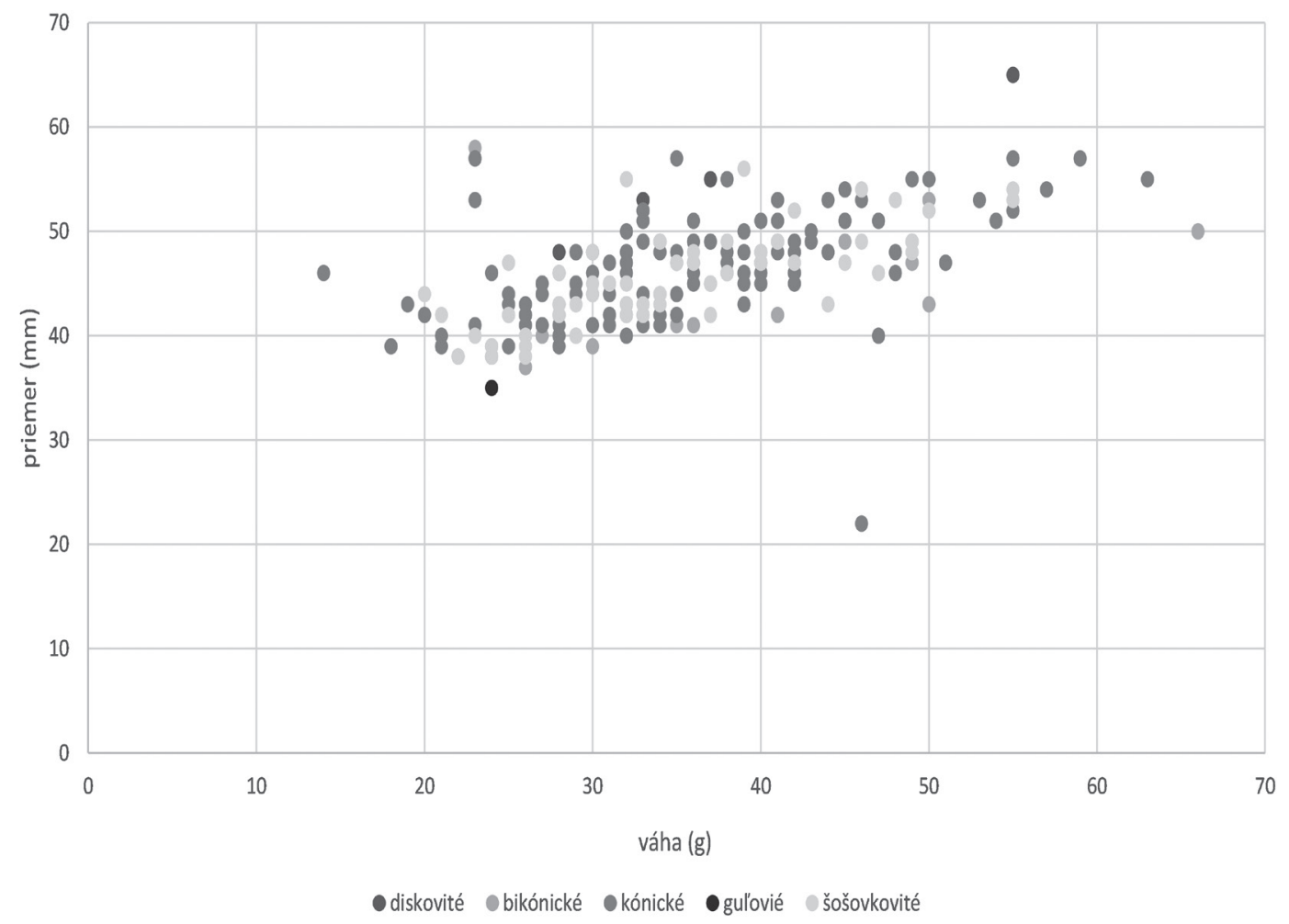

Graf 2. Distribúcia praslenov hmotnost'/priemer, N=219.

Graph 2. Distribution of spindle whorls by weight and diameter, $N=219$.

vyplýva, že nit na lokalite Hlinsko, bola jemnejšia a tenšia, podobne ako na iných eneolitických lokalitách, napr. Čechovice a Čubernice, ktoré boli v rámci tohto projektu tiež nanovo spracované. Ťažšie prasleny boli súčastou vretena, pomocou ktorého sa priadla nit pevnejšia a hrubšia alebo sa využívali k súkaniu.

Prasleny nájdené spolu v jednotlivých objektoch sú si často vel'mi podobné, či už tvarom alebo rozmermi. Všimnút si to môžeme napríklad pri objekte č. 1 z roku 1974, kde sa prasleny 257-40/74 až 257-46/74, ktorých tvar je kónický a bikónický, svojím priemerom a hmotnostou sa pohybujú medzi 43-55 mm a 41-50 g. Rovnako to je aj s objektom č. 14 z roku 1974, kde sú všetky prasleny kónického tvaru, hmot- nost' je v intervale 32-33 g a priemer 42-48 mm. V objekte č. 2 z roku 1969 sú prasleny tiež rovnakého tvaru, no ich hmotnost̉ je menšia a to od 23-38 g, ich priemer sa pohybuje od 41 do $57 \mathrm{~mm}$. Spomínaná skupina praslenov je lahšia oproti ostatným, je možné, že sa tieto prasleny používali na pradenie tých najjemnejších nití. Medzi d’alších zástupcov skupín s praslenmi, ktorí majú l’ahšiu alebo priemernú hmotnost' je objekt č. $7 \mathrm{z}$ roku 1977. V tomto objekte sa našlo 25 praslenov, 15 z nich je kónického tvaru, 8 šošovkovitých a dve bikónické9 . Prasleny sú takmer identické svojimi rozmermi, ich priemer je od 38 do $48 \mathrm{~mm}$, a hmotnostou, ktorá sa pohybuje v rozmedzí od 24-42 g. Zdanlivo vel'ké rozmedzie je spôsobené dvoma pras- 


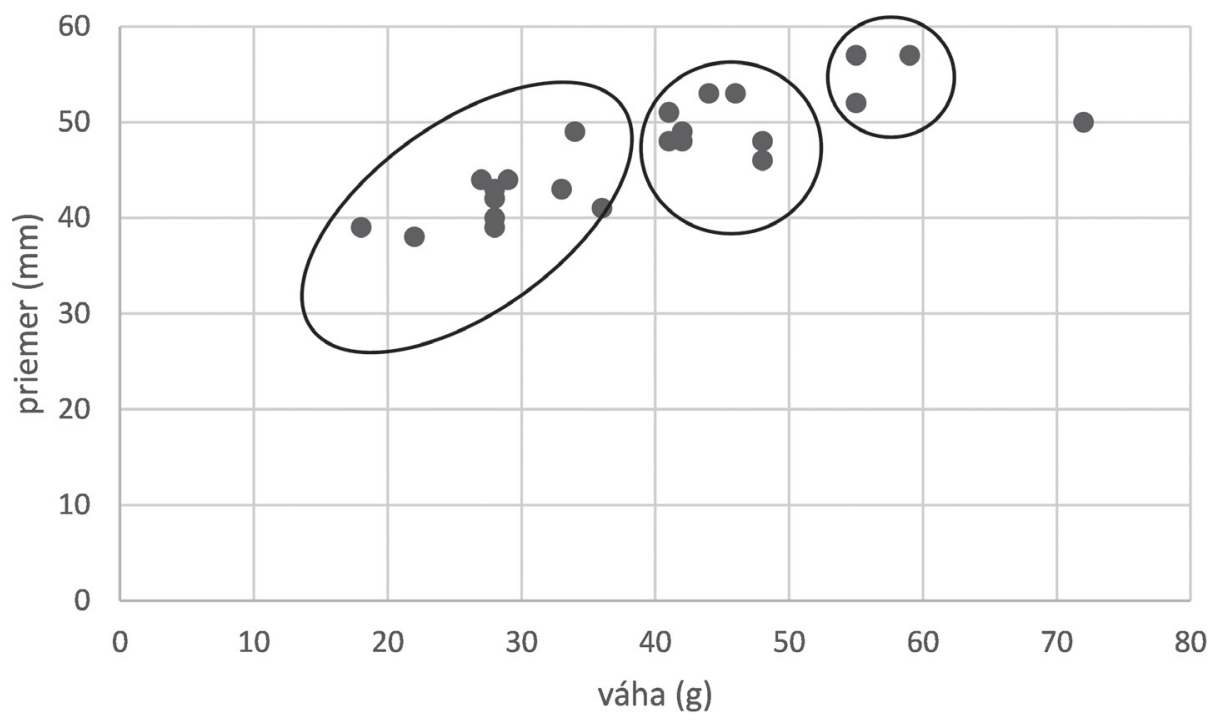

Graf 3. Rozdelenie praslenov do troch skupín z objektu 9 z roku 1975.

Gtraph 3. Distribution of spindle whorls from feature 9 excavated in the year 1975.

lenmi a to tým najväčším a najmenším. Ak by sme ich nechali stranou, tak priemerný priemer a hmotnost' by boli 41,7 mm a $33 \mathrm{~g}$.

Medzi objekty, v ktorých sa naopak nachádzajú rozmanitejšie prasleny, patrí objekt č. 9 z roku 1975. V ňom sú zoskupené prasleny do troch hlavných skupín: 1. skupina najlahších praslenov, ktorých hmotnost' sa pohybuje okolo $30 \mathrm{~g}$, 2. skupina praslenov s hmotnostou medzi $40-50 \mathrm{~g}$ a 3. skupina praslenov s hmotnostou nad $55 \mathrm{~g}$. So zvyšujúcou hmotnostou sa úmerne zvyšuje aj ich priemer. Objekty zastúpené rôznymi typmi praslenov naznačujú rozmanitejšiu výrobu nití (Graf 3).

$\mathrm{V}$ analyzovanej vzorke je len 8 praslenov s výzdobou. Časté sú tri bodky na rovnej strane praslenu a línie. Na predmete 03940-1232/77 sú to tri skupiny po troch líniách v okolí diery praslenu na jeho rovnej strane. V zbierke sa nachádza aj praslen s líniami, ktoré pripomínajú písmo - praslenu už bola venovaná pozornost’ v literatúre (Pavelč̌k 1983, Drechsler ND). Všetky ornamenty sú ryté.

Sietová analýza vytvorená v programe Gephi (softvér na analýzu a vizualizáciu grafov a sietí) zobrazuje vztah medzi typom praslenu a jeho hmotnostou (Obr. 3). Jednotlivé body znázorňujú lokalitu, dané typy a hmotnostné rozpätie. Váha čiar znázorňuje množstvo predmetov s danými vlastnostami. Z obrázku je zrejmé, že najviac praslenov je kónických ako to bolo spomenuté už vyššie, a tieto prasleny majú najčastejšiu hmotnost' medzi 30-40 g, častá je i hmotnost' 20-30 g. Všeobecne môžeme povedat', že ide o lahšie prasleny. Šošovkovité prasleny sú priemerne lahšie a ich hmotnost' sa najčastejšie pohybuje v rozmedzí 20-30 g. Hmotnost bikónických a diskovitých praslenov je rozložená rovnomerne do všetkých intervalov. Pätnást’ praslenov je tažších viac ako $50 \mathrm{~g}$. 


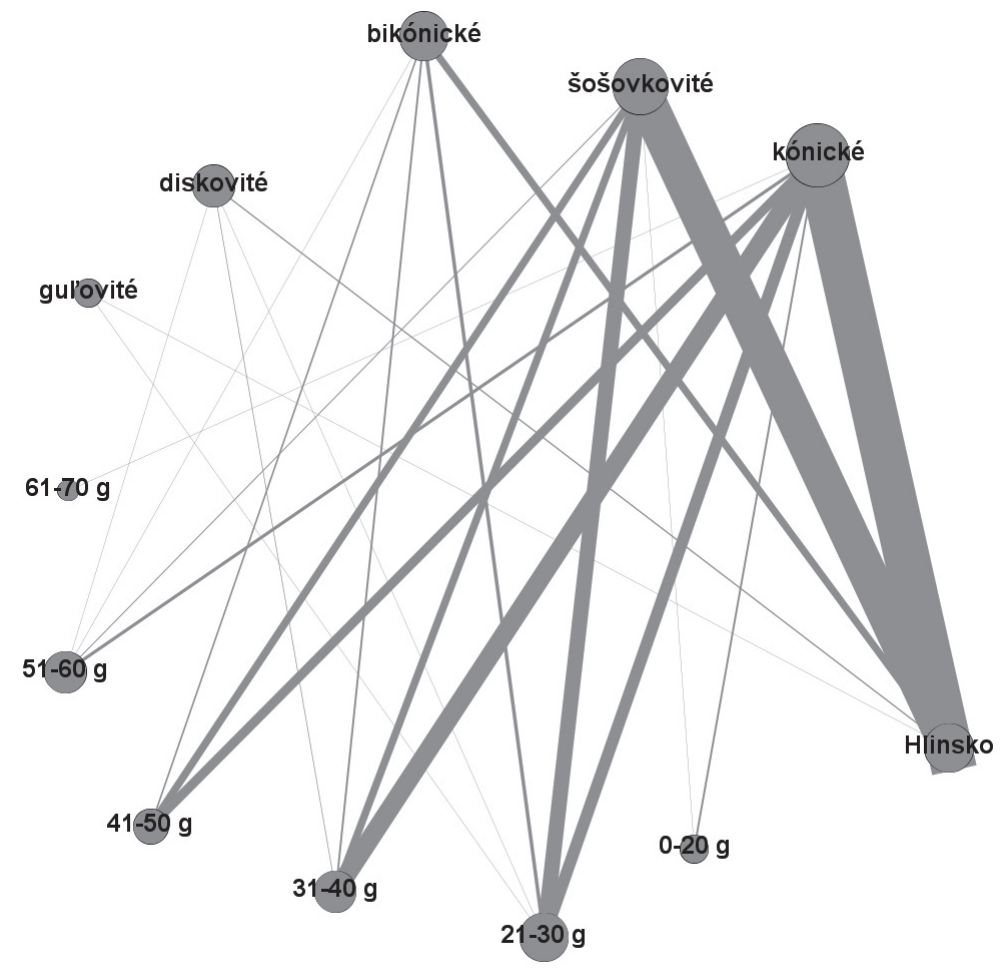

Obr. 3. Siet'ová analýza, Hlinsko: typy a hmotnosti praslenov.

Fig. 3. Network analysis, Hlinsko: types and weight of spindle whorls.

\subsection{Tkáčske závažia}

V analyzovanej vzorke nástrojov na výrobu textilu sa nachádzalo 114 tkáčskych závaží, pričom Pavelčík uvádza ich celkový počet 310 kusov (Pavelčík 1983, 304). Závažia boli častejšie ako prasleny vo fragmentárnom stave, čo sa dalo predpokladat, ked'že ide o väčšie a menej kompaktné (menej dôkladne vypálené) nástroje. Najčastejšie zachované sú fragmenty horných častí závaží, čo spôsobuje problémy pri dopočítavaní celkovej hmotnosti závaží. Ich tvar nie je rovnomerný a nedá sa preto predpokladat, že menšia vrchná čast̉ váži rovnako ako spodná, ktorá je objemnejšia. Preto som sa pri analýze hmotnosti závaží snažila pristupovat jednotlivo k skupinám závaží nájdených na jednom mieste a určit, či mohli byt’ z jedných krosien, ked’že s ohladom na rovnomerné zataženie osnovy je potrebné mat̉ sadu podobných závaží.

Závažia sú vyrobené z pálenej hliny, oranžovo-okrovej farby, časté sú čierne znaky po ohorení. V študovanej vzorke sa nenachádzali žiadne závažia s výzdobou, i ked' Pavelčík spomína štyri zdobené kusy (Pavelčík 1983, 307).

Kónický tvar je najtypickejší, tvorí $81 \%$ vo vzorke, gulovitý tvar je doložený len pri dvoch kusoch, 31 kusov závaží bolo neznámeho tvaru. Vo väčšine prípadov ide o predmety vo fragmentárnom stave. Domnievam sa ale, že väčšina fragmentov závaží pochádza aj tak z kónických závaží. Fragmenty boli totiž často nájdené 
spolu s inými kónickými závažiami a aj vizuálne by to odpovedalo.

Kónické závažia majú výšku od $10-15 \mathrm{~cm}$, najčastejšie sa pohybujú okolo $13 \mathrm{~cm}$. Šírka jednotlivých závaží sa najčastejšie pohybuje medzi 5,5 až $7 \mathrm{~cm}$. Všetky analyzované závažia majú len jeden otvor na zavesenie nití. $\mathrm{Na}$ otvore možno sledovat’ stopy po používaní, hrany otvoru sú opotrebované, zväčšujú sa smerom von, ryhy vznikli od nití, na ktorých boli závažia upevnené. Opotrebovanost hrán kónických závaží svedčí o vzájomnom trení jednotlivých závaží o seba navzájom pri tkaní. Podstava závaží je takmer štvorcová, hrúbka závažia je však vždy o cca centimeter alebo dva väčšia ako ich šírka. Vo vrchnej časti sú kónické závažia zúžené na 3,5 až $6,3 \mathrm{~cm}$, najčastejšie okolo $4,8 \mathrm{~cm}$.

Ako dnes už vieme, medzi najdôležitejšie údaje ovplyvňujúce kvalitu výslednej tkaniny patrí hmotnost̉ a šírka celej rady závaží. Hmotnost’ určuje počet a kvalitu nití uviazaných na jednom závaží a šírka celej rady závaží určuje šírku a hustotu tkaniny (Mårtensson et al. 2009, 373). V objekte 14 z roku 1974 označenom Pavelčíkom ako chata sa našlo 11 závaží a 4 prasleny. Závažia zachované vcelku sú takmer identické, v priemere vážia $637 \mathrm{~g}$ (nebolo započítané jedno závažie 257-1243/74, ktoré váži 1244 g). Hrúbka jednotlivých závaží sa pohybuje od 7,4 po $8,4 \mathrm{~cm}$. Sedem z týchto závaží nachádzajúcich sa severozápadne od pece podla Pavelčíka na základe nálezovej situácie pochádza z jedných krosien (Pavelčik et al. 1975). V objekte 15 z roku 1981, ktorý je takisto označený ako chata sa našlo 10 závaží, sú lahšie ako tie predchádzajúce, ich priemerná hmotnost̉ je 432 g (započítané sú len vcelku zachované závažia), hrúbka je $6,4 \mathrm{~cm}$. Jedenást závaží pochádza z objektu 10 z roku 1985, definovaného ako hliník, ide o skupinu asi najlepšie zachovaných závaží, ich priemerná hmotnost̉ je 389 g a hrúbka jednotlivých závaží sa pohybuje od 7 do 8,3 cm (Obr. 4).

\subsection{Možná výsledná tkanina}

V nasledujúcich riadkoch na dvoch konkrétnych príkladoch vysvetlím, ako mohla výsledná tkanina vyzerat po utkaní dvoma rozličnými skupinami závaží z Hlinska. Vybrala som si závažia z objektu 14 z roku 1974 (A) a závažia z objektu 10 z roku 1985 (B). Pri oboch skupinách sa nedá určit šírka tkaniny, pretože nepoznáme presný počet závaží zavesených na osnove. Príklad je treba brat' ale ako jeden z možných scenárov, ked’že nemáme dostatočné informácie k depozičným procesom na lokalite.

Priemer nite určuje aká hmotnost̉ je potrebná na jej napnutie, všeobecne môžeme povedat, že čím je väčší priemer nite, tým väčšie napnutie nit vyžaduje (Mårtensson et al. 2009, 378). Žial', z Hlinska nemáme zachované nite, preto hmotnost' potrebná na napnutie jednej nite sa dopočítava $\mathrm{z}$ hmotnosti praslenov. Pri tomto dopočítavaní vychádzam z experimentov Mårtensson et al. $2009^{10}$. To znamená, že s 18 g praslenom upriadli nit, ktorej priemer bol 0,4-0,6 mm a následne táto nit potrebuje zataženie 25-30 g aby bola napnutá.

A: V prípade objektu 14 z roku 1974 máme prasleny o hmotnosti 32-40 g. Pokial' predpokladáme, že práve tieto prasleny boli použité k pradeniu nití následne použitých pri tkaní, tak hmotnosṫ potrebná na ich napnutie by bola približne medzi $30 \mathrm{~g}$ až 40 g. ${ }^{11}$ Hmotnost̉ závaží je 637 g, hrúbka 1 závažia je 76 mm. Podla týchto informácií vieme dopočítat počet nití na jednom závaží. Pri tenších nitiach, ktoré potrebujú 30 g napnutie bude upevnených 21 nití na 1 závaží a pri hrubších, ktoré potrebujú $40 \mathrm{~g}$ napnutie to bude 16 nití na 1 závaží (Tab. 1). Ked’že, jedno závažie s napnutými nitami sa nachádza v prednej časti a druhé v zadnej, počet osnovných nití sa zdvojnásobí, pri $30 \mathrm{~g}$ to bude 42 nití a pri 40 g to bude 32 nití. Počet osnovných nití na dvojicu závaží (predná a zadná 


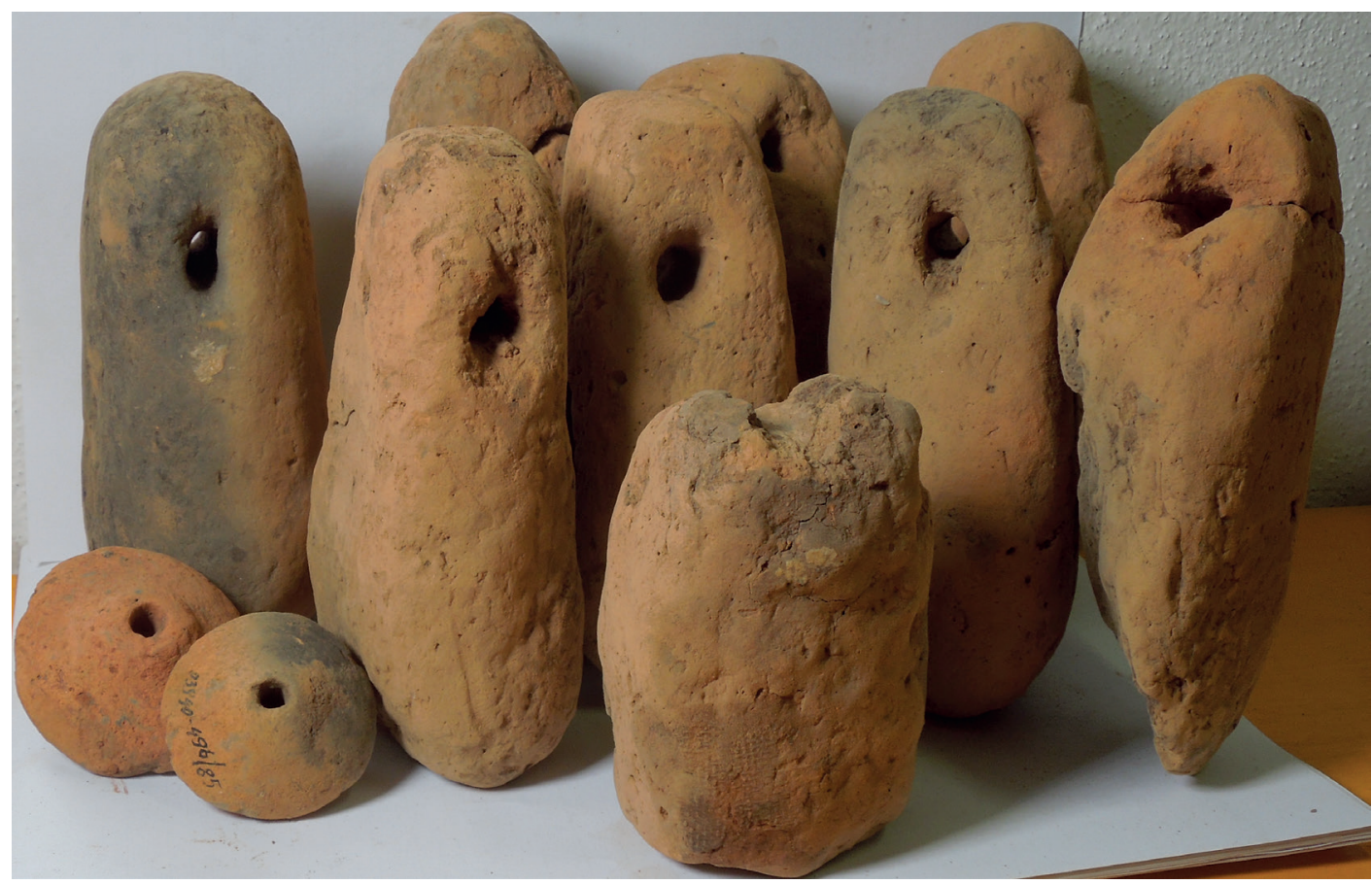

Obr. 4. Tkáčske závažia spolu s dvoma praslenmi z objektu 10 z roku 1985 (inv. čísla: 03940-495/85, 03940496/85, 03940-497/85, 03940-498/85，03940-499/85，03940-500/85，03940-501/85，03940-502/85, 03940-504/85, 03940-506/85, 03940-507/85). Fotografia autorka v Múzeu Komenského v Přerově.

Fig. 4. Loom weights with two spindle whorls from feature 10 excavated in the year 1985. (Inv. Num.: 03940495/85, 03940-496/85, 03940-497/85, 03940-498/85, 03940-499/85, 03940-500/85, 03940-501/85, 03940$502 / 85,03940-504 / 85,03940-506 / 85,03940-507 / 85)$. Photo by author in Komenský Museum in Přerov.

časti) sa vydelí hrúbkou závažia a získa sa počet osnovných nití na centimeter (Tab. 2). Pri napnutí osnovnej nite na $30 \mathrm{~g}$ je to 5 osnovných nití na $\mathrm{cm}$ a pri $40 \mathrm{~g}$ sú to 4 osnovné nite na cm. Z Tab. 3 je zjavné, že práve $30 \mathrm{~g}$ napnutie nite je najideálnejšou možnostou, tkanie s príliš tenkými nitami by viedlo $\mathrm{k}$ vel'kému množstvu nití na tkáčskom závaží a tkanie by bolo príliš komplikované. Pri napnutí na 40 g je tkanie možné, ale počet nití na jeden cm už bude nižší.

B: V prípade objektu 10 z roku 1985 máme prasleny o hmotnosti 25-32 g. Pokial' predpokladáme, že práve tieto prasleny boli použité k pradeniu nití následne použitých pri tkaní, tak hmotnost' potrebná na ich napnutie by bola približne medzi $30 \mathrm{~g}$ až $40 \mathrm{~g}$. Hmotnost' závaží je 389 g, hrúbka 1 závažia je cca 79 mm. Pri tenších nitiach, ktoré potrebujú 30 g napnutie bude upevnených 13 nití na 1 závaží a pri hrubších, ktoré potrebujú 40 g napnutie to bude 10 nití na 1 závaží (Tab. 1). Ked’že, jedno závažie s napnutými nitami sa nachádza v prednej časti a druhé v zadnej, počet osnovných nití sa zdvojnásobí, pri $30 \mathrm{~g}$ to bude 26 nití a pri $40 \mathrm{~g}$ to bude 20 nití. Počet osnovných nití na dvojicu závaží (predná a zadná čast') sa vydelí hrúbkou závažia a získa sa počet osnovných nití na centimeter (Tab. 2). Pri napnutí nite na 30 g sú to 3 osnovné nite na $\mathrm{cm}$ a pri $40 \mathrm{~g}$ sú to $2-3$ 


\begin{tabular}{|l|c|c|}
\hline Hmotnost' závažia & $\mathbf{6 3 7} \mathbf{~ g}$ & $\mathbf{3 8 9} \mathbf{g}$ \\
\hline $30 \mathrm{~g}$ napnutie & 21 nití na 1 závaží & 13 nití na 1 závaží \\
\hline 40 g napnutie & 16 nití na 1 závaží & 10 nití na 1 závaží \\
\hline
\end{tabular}

Tab. 1. Vypočítaný počet nití pri rôznom napnutí nití na 637 g a 389 g závažiach.

Tab. 1. Calculated number of threads at different thread tensions on $637 \mathrm{~g}$ and $389 \mathrm{~g}$ loom weights.

\begin{tabular}{|l|c|c|c|c|}
\hline & \multicolumn{2}{|c|}{$\mathbf{6 3 7} \mathbf{~ g , ~ h r u ́ b k a ~ 1 ~ z a ́ v a z ̌ i a ~ j e ~ 7 6 ~ m m ~}$} & \multicolumn{2}{c|}{$\mathbf{3 8 9} \mathbf{~ g}$, hrúbka 1 závažia je 79 mm } \\
\hline napnutie & $30 \mathrm{~g}$ & $40 \mathrm{~g}$ & $30 \mathrm{~g}$ & $40 \mathrm{~g}$ \\
\hline počet nití na 1 závaží & 21 & 16 & 13 & 10 \\
\hline počet nití na 2 závaží & 42 & 32 & 26 & 20 \\
\hline počet osn.nití na cm & 5,5 & 4 & 3 & $2-3$ \\
\hline
\end{tabular}

Tab. 2. Výpočet osnovných nití pri ich rôznych napnutiach, pri hmotnosti závaží 637 g a 389 g, hrúbka závaží 76 $\mathrm{mm}$ a $79 \mathrm{~mm}$.

Tap. 2. Calculation of various loom setups with loom weights of $637 \mathrm{~g}$ and $389 \mathrm{~g}$, thickness of loom weight 76 $\mathrm{mm}$ and $79 \mathrm{~mm}$.

\begin{tabular}{|c|c|c|c|c|c|c|c|c|c|c|c|}
\hline \multirow{2}{*}{\multicolumn{2}{|c|}{ napnutie osnovnej nite }} & \multicolumn{5}{|c|}{637 g, hrúbka 1 závažia je 76 mm } & \multicolumn{5}{|c|}{389 g, hrúbka 1 závažia je 79 mm } \\
\hline & & $10 \mathrm{~g}$ & $20 \mathrm{~g}$ & $30 \mathrm{~g}$ & $40 \mathrm{~g}$ & $50 \mathrm{~g}$ & $10 \mathrm{~g}$ & $20 \mathrm{~g}$ & $30 \mathrm{~g}$ & $40 \mathrm{~g}$ & $50 \mathrm{~g}$ \\
\hline \multirow{2}{*}{$\begin{array}{l}\text { počet } \\
\text { osnovných } \\
\text { nití }\end{array}$} & na 1 závažie & 63,7 & 32 & 21 & 16 & 13 & 39 & 19 & 13 & 10 & 8 \\
\hline & na 2 závažia & 127 & 64 & 42 & 32 & 26 & 78 & 38 & 26 & 20 & 16 \\
\hline \multicolumn{2}{|c|}{ osnovné nite na cm } & 17 & 8 & 5,5 & 4 & 3 & 10 & 5 & 3 & $2-3$ & 2 \\
\hline
\end{tabular}

Tab. 3. Výpočty pre rozličné zat'aženia tkáčskych závaží.

Tab. 3. Calculations of various loom setups.

osnovné nite na cm. Z Tab. 3 môžeme zhrnút, že najideálnejšie sa bude tkat' s nitami, ktoré potrebujú 30 g napnutie, možné je i tkanie s napnutím nite na $40 \mathrm{~g}$. Tkanie s nitami, ktoré potrebujú $50 \mathrm{~g}$ napnutie by bolo možné čo sa týka počtu naviazaných nití na jednom závaží, ale počet osnovných nití na jednom $\mathrm{cm}$ by už bol príliš nízky.

$\mathrm{V}$ oboch prípadoch som síce pracovala $\mathrm{s}$ hmotnostou praslenov $\mathrm{z}$ daného objektu, ale práve hmotnost́ praslenov v rozmedzí 30-40 g je najčastejšou hmotnostou vyskytujúcou sa na lokalite. Vd’aka kónickému tvaru závaží je možné na každé závažie naviazat viac nití (a zvýšit tak hustotu osnovných nití) oproti závažiu o tej istej hmotnosti cylindrického tvaru (Belanová-Štolcová - Grömer 2009, 17, obr. 3.10).

Zaujímavostou hodnou povšimnutia je odtlačok tkaniny na závaží 03940-506/85. Ide o jednoduchú plátnovú väzbu s dostavou $7 / 3$ a s priemerom nite cca $1,1 \mathrm{~mm}$ (Obr. 5). Tento priemer nite odpovedá tomu, že nit bola upradená praslenmi približne o hmotnosti $40 \mathrm{~g}$, ktoré sú pre lokalitu typické. Následne, práve $40 \mathrm{~g}$ napnutie nite, ktoré je vhodné pre nit o priemere $1,1 \mathrm{~mm}$, je najideálnejšie pri tkaní so závažiami nájdenými na lokalite. Materiál ani typ zákrutu nite nebolo možné určit. 


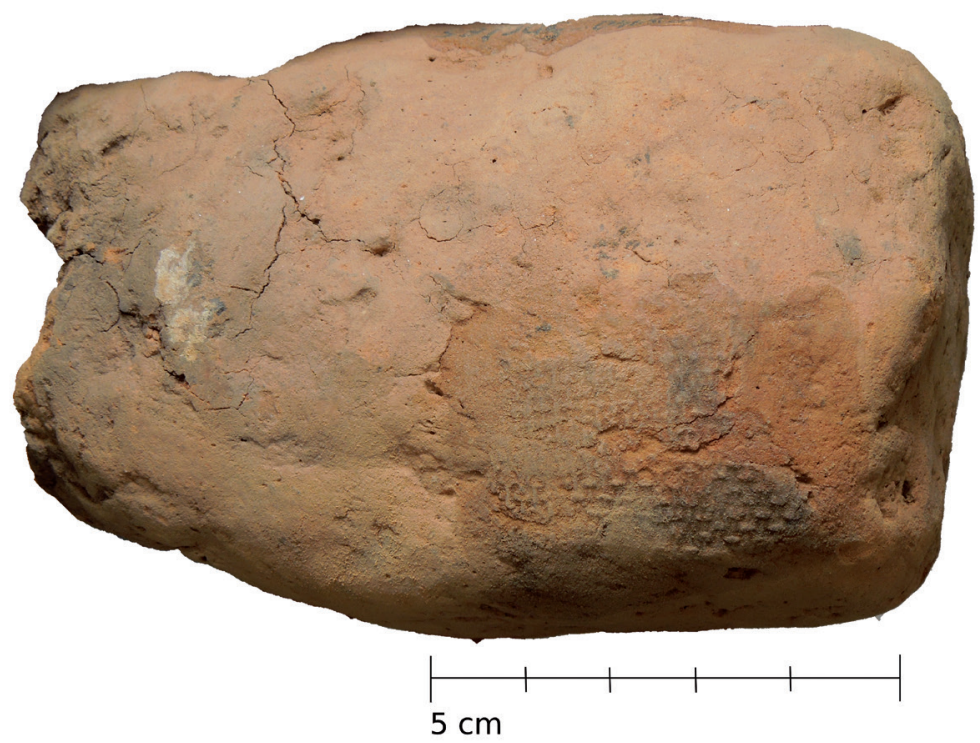

Obr. 5. Závažie s inv. číslom 03940-506/85 s odtlačkom tkaniny. Fotografia autorky v Múzeu Komenského v Přerově.

Fig. 5. Loom weight Inv. Num. 03940-506/85 with fabric imprint. Photo by author in Komenský Muszeum in Přerov.

\section{Diskusia}

\subsection{K datovaniu spracovaných nálezov}

Predmety spojené s textilnou výrobou nie sú chronologicky citlivý materiál a ich časové priradenie je vždy na základe keramických nálezov v relevantných objektoch. Samozrejme, mohlo a v niektorých prípadoch i dochádzalo $\mathrm{k}$ postdepozičným procesom a teda len predmety nájdené in situ môžu byṫ datované s určitostou (podla nálezových správ závažia v objektoch 15 z roku 1981 a objektu 14 z roku 1974). Eneolitické osídlenie Hlinska bolo Pavelčíkom rozdelené do piatich sídelných horizontov, pričom študované predmety patria najmä do prvého sídelného horizontu, predbolerázskeho, a do druhého sídelného horizontu, bolerázskeho. Hradisko bolo počas prvých štyroch horizontov osídlené bez prestávky, a preto vymedzenie jednotlivých sídlisko-chronologických horizontov nie je vždy jasné. Podla tvarov keramiky sa v niektorých prípadoch nedá spolahlivo určit, do ktorej fázy badenskej kultúry daný nálezový celok patrí (Šebela et al. 2007, 153). Spracované predmety boli navyše často súčastou objektov, v ktorých sú zaznamenané intrúzie, súvisiace so stavebnou činnostou v nasledujúcich horizontoch. Napriek tomu môžeme zhruba skonštatovat, že spracovaná vzorka praslenov pochádza $\mathrm{z}$ väčšej časti z druhého sídelného horizontu, s tým, že niektoré z nich bolo možné d'alej bližšie zadatovat do fáz BK Ia a BK Ib, Graf 4.

Po zhodnotení rozmerov, hmotnosti a priemeru, nie sú viditelné značné rozdiely medzi praslenmi z predbolerázskeho $(\mathrm{PBH})$ a neskoršieho bolerázskeho obdobia (BK I), Graf 5 . Všeobecne, prasleny z predbolerázskeho obdobia sú skôr lahšie a menšie, k ním sa zhlukujú i prasleny pochádzajúce z badenských objektov, 


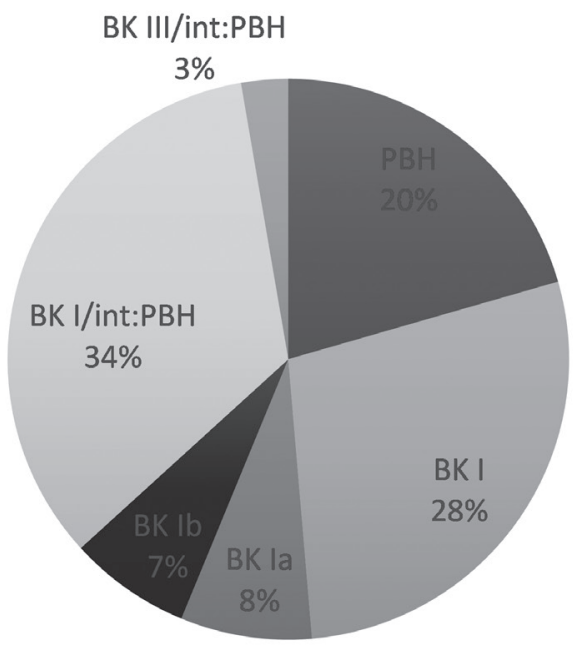

$\square \mathrm{PBH} \square \mathrm{BKI} \square \mathrm{BK}$ la $\square \mathrm{BK} \mathrm{Ib} \backsim \mathrm{BK} \mathrm{I} / \mathrm{int}: \mathrm{PBH} \quad \mathrm{BK}$ III/int:PBH

Graf 4. Rozdelenie študovaných praslenov do jednotlivých stupňov BK.

Graph 4. Distribution of studied spindle whorls based on phases of Baden culture.

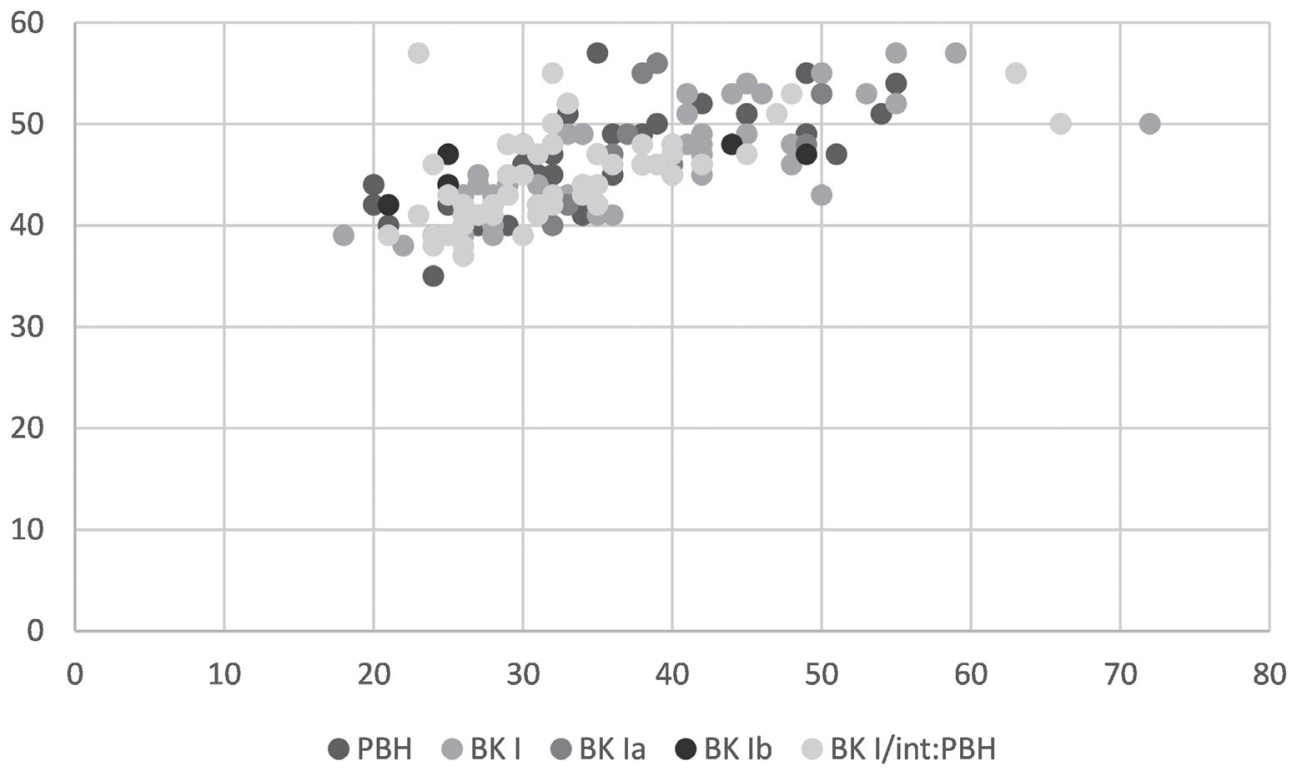

Graf 5. Distribúcia praslenov hmotnost'/priemer - datovanie, N=211.

Graph 5. The weight-diameter distribution for periods, N=211. 
kde bola zaznamenaná intrúzia z predbolerázskeho obdobia. Prasleny z objektov zaradených len obecne do stupňa BK I, ktoré nebolo možné presnejšie zaradit, pretože obsahovali len zlomky keramiky, boli rozmerovo najrozmanitejšie. Objekty, v ktorých boli dochované študované závažia sú datované všetky do druhého sídelného horizontu (BK I), v štyroch z nich bola intrúzia z predbolerázskeho horizontu, závažia z čisto predbolerázskeho horizontu sa vo vzorke nenachádzajú, preto predpokladám, že tkáčske závažia zo štyroch zmiešaných objektov sa používali až v druhom horizonte (BK I), teda bolerázskom. Tento záver podporuje i fakt, že závažia z týchto zmiešaných objektov sú vizuálne podobné tým, ktoré patria práve už do bolerázskeho horizontu. Z neskorších horizontov, teda tretieho a štvrtého (korešpondujúcich fázam BK II a BK III) tkáčske závažia v mojej vzorke dochované nie sú, čo je samo o sebe tiež zaujímavé a zaslúžilo by si d’alšiu úvahu.

\subsection{K určeniu materiálu používaného na textilnú výrobu}

Určenie materiálu používaného v textilnej výrobe je jedným z najdôležitejších faktorov, vd’aka ktorému je možné ozrejmit celý proces výroby textilu. Textilná výroba patrí medzi časovo náročné činnosti, a preto z vel'kej časti zasahovala a ovplyvňovala život ludí. Všetky fázy výroby textilu sa v čase vyvíjali a dochádzalo k sociálnym (napr. špecializácia) a technologickým (napr. triedenie vláken na základe kvality) zmenám.

V paleolite a mezolite sa používali lyká stromov a trávy na výrobu povrazov, sieti, častí oblečenia apod. Antoinette Rast-Eicher podotýka, že v neolite bola textilná výroba založená na spracovávaní rastlinných vláken, čo má pôvod práve v mezolite a paleolite (Rast-Eicher 2005, 117-120). Na tomto mieste by som rada upozornila na rôzne podmienky zachovania vláken: vlákna rastlinného pôvodu lahšie podliehajú rozkladu, obsahujú celulózu a teda sú lepšie dochované v zásaditom prostredí, naopak pre živočíšne s obsahom proteínu je lepšie prostredie kyslé. Absencia živočćšnych vláken môže byt' preto zapríčinená aj nevhodnými podmienkami dochovania (Cybulska - Maik 2007). Dobrým príkladom sú Alpské mokrade, kde sa objavilo mnoho lanových textílií, a pokial' by sa v tomto prostredí i využívali vlákna živočíšneho pôvodu, tak by sa nedochovali. Lanové semená sa ako prvé objavovali na Blízkom východe, kde sú datované už od 9. tisícročia pred naším letopočtom (Helbak 1959). V Európe vykopávky v Alpskom regióne naznačujú pestovanie ako aj špecializovanú výrobu lanu na textilnú výrobu od 4. tisícročia pred naším letopočtom (Maier - Schlichtherle 2011). Z oblasti Moravy môžeme spomenút nález petrifikovanej tkaniny z obdobia kultúry s lievikovitými pohármi z Náměště na Hané (Šmíd 2003, 36) a šnúrky náhrdelníku z Ivanovic na Hané (Kolář et al. 2011, 192-193) zo ženského hrobu z obdobia so šnúrovou keramikou. $\mathrm{V}$ oboch prípadoch ide o rastlinné vlákna, v Ivanovicích s najväčšou pravdepodobnostou o konope (Kolár et al. 2011, 188, 193).

Z výskumu Christopha Herbiga a Ursuly Maier, ktorý skúmal eneolitické sídliska na juhozápade Nemecka a d’alšieho, ktorý porovnával rozmery súčasných a zachovaných semien lanu (Herbig - Maier 2011; Karg - Diederichsen - Jeppson 2018, 31-38), je zrejmé, že vel'kost̉ semien lanu určuje ich následné využitie. Táto diferenciácia v Európe prebehla v eneolite. Semená z obdobia 4000-3400 pred naším letopočtom sa výrazne lísia od neskorších, teda po roku 3400 pred naším letopočtom. Hlavným rozdielom je ich vel'kost', ktorá sa s postupom času zmenšovala, väčšie semená mohli slúžit ako na výrobu vláken tak na výrobu oleja, menšie už slúžia a sú vhodné len na výrobu vláken, čo podporuje i fakt, že lokality, na ktorých sa našli sú doloženými centrami textilnej výroby 
(Herbig - Maier 2006, 527-533). Menší typ semien bol vyšlachtený v Európe alebo sa sem rozšíril z Blízkeho východu (Karg - Diederichsen - Jeppson 2018, 31). Evolúcia a domestikácia lanu nie je dodnes presne známa podobne ako jeho šírenie z miesta pôvodu, objavenie a vývoj rôznych možností jeho využitia (Fu - Allaby 2010). O využívaní lanu v Hlinsku svedčia nálezy semien z viacerých objektov. Semená sú v zuhol'natenom stave, ich morfologická analýza nie je možná, ide o zhluky semien, ktorých vel'kost' sa pohybuje $4 \times 3 \times 2,5 \mathrm{~cm}$ ako je napríklad vzorka 1821 z roku 1976, d’alšími príkladmi sú zhluky o priemere $5 \mathrm{~cm}$ zo sondy 70 z roku 1982 a d’alšie nálezy z rokov 1979, 1981, 1984. ${ }^{12}$ Síce z týchto vzoriek nie je možné určit, či sa semená l’anu využívali v rámci textilnej výroby alebo na výrobu oleja, minimálne jeden jeho nález a to z objektu 5 z roku 1984 s ňou spájaný byt môže, ked’že spolu s ním boli v objekte 3 prasleny a 11 závaží. Najpravdepodobnejšie je, že lanové semená z Hlinska boli využívané synergicky, teda k výrobe vláken ako aj oleja.

V eneolite došlo k výraznému ekonomickému a technologickému rozvoju. Tieto inovácie medzi ktoré patrí i používanie vlny, Andrew Sherratt nazval revolúciou druhotných produktov. Model Andrewa Sherratta (Sherratt 1981) predpokladá prvotnú domestikáciu dobytka na konzumáciu mäsa, druhotné produkty ako mlieko, vlna sa začali využívat’ až neskôr - tento predpoklad minimálne $\mathrm{v}$ oblasti využívania mlieka bol medzičasom už vyvrátený (Evershed et al. 2008). Sherrattov model je príliš skokovitý, akoby sa neolitickí l’udia sústredili len na chov dobytka kvôli mäsu a až neskôr zistili, že sa zvieratá môžu využívat i na získavanie iných produktov. Tým, že kvalita vlny sa zlepšovala selekciou, musel tento proces trvat dlhé obdobie a teda musel začat ovela skôr, ked'že v 3 . tisícročí už v Mezopotámii mala vlna popredné miesto v ekonomike (Charvát 2011) a výskumy z Blízkeho východu uvádzajú (na základe zooar- cheologických dát), že vlna bola využívaná už krátko po prvotnej domestikácií oviec (Vila Helmer 2014). Z nálezov kostí vieme, že domáce zvieratá ako ovca alebo koza bola v Európe už od neolitu (Grömer 2016, 54). Prvé plemená oviec mali krátku srst', vlnené plemeno ovce bolo prítomné v strednej Európe najskôr v 4. až 3. tisícročí pred naším letopočtom (Lüning et al. 1997, 69), nálezy vlny použitej na textil sú z 3. tisícročia pred naším letopočtom ${ }^{13}$. Analýza Reného Kyselého, poukazuje na to, že sa od starého do mladého eneolitu postupne zvyšuje počet kostí oviec a kôz, ktoré sú už vhodné na produkciu sekundárnych produktov ako mlieka a vlny, avšak išlo o kombinované využívanie na mäso, mlieko, vlnu (Kyselý 2012, 49) ${ }^{14}$. V Hlinsku patrí najviac kostí domácim zvieratám v porovnaní s lovenou zverou, ovciam a kozám patrí druhé miesto hned' za turom (Šebela et al. 2007, 265). I napriek tomu sa zdá byt podiel ovci/kôz v Hlinsku nízky oproti iným lokalitám z tohto obdobia (Nývltová-Fišáková - Kratochvíl 2007).

V mnohých prípadoch sa pri štúdiu použí vaných vláken musíme spolahnút na nepriame dôkazy a to prasleny - textilných zvyškov je v našom prostredí zachovaných vel'mi málo. Rôzne typy vláken vyžadujú iný spôsob pradenia, krátke a jemnejšie vlákna sa oproti dlhším a hrubším musia priast’ rýchlejšie, aby vyšší počet zákrutov zabezpečil spojenie vláken (Chmielewski - Gardyński 2010, 876). Z 238 praslenov bolo na analýzu použitých 221 praslenov. Najprv som si definovala minimá a maximá rozmerov a hmotnosti ako aj pomerov priemer/ hmotnost’ a výška/priemer (Tab. 4). Ďalej sú prasleny rozdelené do kategórií na základe výšky/priemer a váhy (Tab. 5). Výškové kategórie sú rozdelené na základe delenia Any Grabundžije (Grabundžija - Russo 2016, 301-326), ktorá robila analýzu praslenov z Panónskej nížiny, avšak sú prispôsobené študovanej vzorke (bolo by nelogické do nej zahŕňat rozmer, ktorý sa 
Predmety používané pri výrobe textilu z Hlinska - Nad Zbružovým. Analýza praslenov a tkáčskych závaží ...

\begin{tabular}{|l|c|c|}
\hline $\mathbf{N}=\mathbf{2 2 1}$ & Min. & Max. \\
\hline priemer & 22 & 65 \\
\hline výška & 11 & 34 \\
\hline priemer otvoru & 4 & 9 \\
\hline hmotnost' $^{\prime}$ & 14 & 72 \\
\hline výška/priemer & 0,23 & 1,09 \\
\hline hmotnost'/priemer & 0,304 & 1,4 \\
\hline
\end{tabular}

Tab. 4. Minimá a maximá rozmerov praslenov.

Tab. 4. Minimum and maximum dimensions of spindle whorls.

\begin{tabular}{|c|c|c|c|}
\hline \multicolumn{2}{|c|}{ výška/priemer (mm) } & \multicolumn{2}{|c|}{ hmotnost' (g) } \\
\hline 0,2 & \multirow{2}{*}{ ploché } & 14 & \multirow{2}{*}{ l'ahké } \\
\hline 0,3 & & 30 & \\
\hline 0,35 & \multirow{2}{*}{ vysoké } & 34 & \multirow{2}{*}{ stredné } \\
\hline 0,52 & & 50 & \\
\hline nad 0,52 & strmé & $\operatorname{nad} 50$ & t’ažké \\
\hline
\end{tabular}

Tab. 5. Rozdelenie praslenov na základe pomeru výšky/priemer a hmotnosti.

Tab. 5. Distribution of spindle whorls based on height/diameter ratio and weight.

v nej ani nenachádza). Pri hmotnostnom rozmedzí som vychádzala z toho, že hranica 30 gramov sa zdá byt najvhodnejšia, ked’že sa pri nej dá uspokojivo priast’ dlhá a tažká vlna (Barber 1991, 52; Gleba 2008, 103-106).

Najviac flexibilné na pradenie rôznych druhov vláken (čo sa týka uhlu zákrutov a napnutia vláken) sú stredne tažké a vysoké prasleny, a to preto, že vysoké prasleny oproti plochým s rovnakou hmotnostou majú nižší moment zotrvačnosti. Pravdepodobne ide o zámernú výrobu vyšších praslenov, ktoré sú vhodné na pradenie kratších a lahších vláken, ktoré vyžadujú viac zákrutov (Chmielewski - Gardyński 2010, 876). Nižší moment zotrvačnosti znamená, že praslen lahšie dáme do pohybu a bude sa rýchlejšie otáčat, ale tým, že hmotnost’ ostane rovnaká, nit ostane dostatočne napnutá. Skupina, v ktorej sú lahké a vysoké prasleny, je takmer rovnako zastúpená ako skupina so stredne tažkými a vysokými praslenmi, najmenej zastúpené sú ploché a tažké prasleny. Použivanie týchto typov praslenov je najčastejšie aj v už spomínanej Panónskej nížine, kde tým, že bolo skúmaných viacero lokalít $\mathrm{z}$ viacerých období sú jednotlivé rozsahy hmotností a rozmerov väčšie (Grabundžija - Russo 2016, 301-326).

Archeologický materiál, jeho morfológia ako aj nálezy nového typu lanu v Európe, vhodnejšieho na výrobu vláken a takisto postupne sa zvyšujúci počet osteologického materiálu oviec v eneolite (Kyselý 2012, 49) naznačuje, že v období 4. tisícročia pred naším letopočtom nastala zmena v textilnej výrobe, ktorá sa udiala následkom celkových zmien spoločnosti a to v ekonomickej a sociálnej oblasti. Tento typ zmeny často nastáva $\mathrm{v}$ dôsledku zmeny klímy, ktorá núti obyvatel'ov prispôsobit sa novým podmienkam na život. Od roku 6500 cal BP začína v Európe obdobie výkyvov medzi suchými a vlhkými obdobiami. Výkyvy mali značne regionálny charakter, v rôznych miestach Európy sa preja- 
vovali rôznymi spôsobmi (Dreslerová 2010, 19). Územie Českej republiky sa nachádza na rozhraní dvoch klimatických sektorov a to medzi stredozápadným a stredovýchodným. Preto sa predpokladá, že výkyvy medzi jednotlivými obdobiami boli na našom území miernejšie ako v iných častiach Európy (Dreslerová 2010, 19). Zhoršenie klimatických podmienok mohlo zapríčinit nižšiu úrodnost̉ rastlín vhodných k textilnej výrobe, došlo $\mathrm{k}$ nedostatku materiálu a to prinútilo ludí $\mathrm{k}$ hladaniu nových materiálov vhodných $\mathrm{k}$ výrobe vláken. Jedným z nich bola kultivácia nového typu lanu, ktorý bol odolnejší a teda vhodnejší k produkcii textilu (Herbig - Maier 2011, 527-533). Medzi d’alšie alternatívy mohlo patrit používanie živočíšnych vláken a to vlny z ovce alebo kozy. Oba druhy zvierat prítomné v sídliskách boli primárne určené ku konzumácií mäsa a produkcii mlieka, ich d’alšie využitie by svedčilo o efektivite využitia všetkých produktov. Čiastočné používanie vlny podporuje i stále sa zvyšujúci dopyt po produktoch z textilu (na základe množstva nájdených praslenov), ktorý bolo náročné uspokojit rastlinnými vláknami, ked’že pestovanie a následné spracovanie lanových vláken je vel'mi zdĺhavé, je k nemu potrebná vel'ká plocha kvalitnej pôdy - z $1000 \mathrm{~kg}$ surového materiálu sa získa len 100 kg vláken (Burke 2010, 10). Ana Grabundžija a Emmanuele Russo predpokladajú, že prechod od používania rastlinných vláken $\mathrm{k}$ živočíšnym na území Panónskej nížiny bol postupný, živočíšne vlákna sa používali len ako doplnkové, až časom sa stali väčšinovým používaným vláknom (Grabundžija - Russo 2016, 319). Tento model šírenia je pravdepodobný aj na území Moravy, alebo aspoň na hradisku Hlinsko.

\subsection{Možnost' špecializovanej textilnej výroby}

Textilná výroba sa vyvíjala rôzne v závislosti na období a mieste, avšak vždy existujú fázy, ktoré sú spoločné pre všetky obdobia a miesta a to: obstarávanie vláken, príprava vláken, pradenie, tkanie a konečná úprava, pričom každá etapa zahŕňa niekol'ko procesov (Andersson Strand 2012, 22). Každá z fáz má priamy vplyv na výslednú nit. Z experimentov vykonaných v Ribe Viking Centre v Kodani ${ }^{15}$ vieme, že každá i malá zmena v prípravnom procese má vplyv na množstvo a kvalitu vláken, a preto príprava vláken patrí medzi dôležité súčasti pri interpretácií textilnej výroby (Andersson Strand 2012, 28). Ako príklady ovplyvňujúce výsledné množstvo a kvalitu vláken si môžeme uviesț: ako boli lanové steblá spracované a jeho vlákna česané, z akého plemena ovce pochádzajú vlákna, z akej časti ovce, ako boli a či boli vlákna triedené apod.

Špecializovaná výroba ako taká sa v eneolite na území Moravy ešte len formuje. Je na odlišných úrovniach v závislosti od rôznych lokalít a odvetví; odvetvia, ktoré si vyžadovali nejakú špeciálnu zručnost’ sa pravdepodobne vyvíjali rýchlejšie, ked’že jeden človek opakoval stále tú istú aktivitu, pokial' nedosiahol želaný výsledok - to by mohol byt prípad napríklad štiepanej industrie (Janák 2009-2010, 253). Tento typ práce je aj lahšie preukázaný na niektorých sídliskách, pretože vyžaduje špecifické miesto v rámci sídliska a produkty alebo materiál potrebný k výrobe je často nájdený práve na jednom konkrétnom mieste. Tým, že hotové produkty ako aj materiál na ich výrobu sa koncentrujú na jedno miesto, je ovela lahšie vyhodnotit proces výroby, používané techniky, intenzitu výroby a tým pádom aj úroveň špecializácie. Ďalšie menej špecifické aktivity, ktoré môže vykonávat väčšinové obyvatel'stvo, často popri iných činnostiach, sa vyvíjali pomalšie, nástroje na ich výrobu a materiál sú roztrúsené po celej lokalite. 
To neumožňuje lokalizáciu konkrétneho výrobného areálu a často pri odkrytí len časti sídliska dochádza ku skresleniu pri interpretácií intenzity danej výrobnej činnosti.

Práve medzi posledný zmienený typ výroby patrí textilná výroba, ktorá sa storočia vykonávala v domácom prostredí. Pradenie je možné vykonávat takmer kdekolvek vo vnútornom i vonkajšom prostredí, dokonca pri chôdzi (Grömer 2005, 109). Zachytenie jednoznačných výrobných priestorov pradenia a tkania v eneolite je takmer nemožné, o to viac je potrebná priestorová analýza nájdených nástrojov na výrobu textilu na sídlisku. Ideálna situácia je, ked’ výskum na lokalite prebiehal systematicky niekol'ko rokov a značná čast́ sídliska je odkrytá, čo je prípad Hlinska. Istý stupeň špecializácie na sídlisku indikujú vel'ké skupiny praslenov, ktoré majú rovnaké rozmery a hmotnost', teda sa nezdá, že by šlo o zoskupenie praslenov jedného človeka, ktorý si podl’a požiadavku vyberá rôzne typy praslenov, ale o skupinu praslenov, ktorá bola používaná k pradeniu nití rovnakej kvality. Pri priestorovej analýze väčších skupín nástrojov na výrobu textilu v Hlinsku som zistila, že študované nástroje sa nachádzali najčastejšie v stredovej časti sídliska. V tejto časti sú doklady iných výrobných procesov, výroba keramiky, zlievačská dielňa apod. (Šebela et al. 2007, 110). Tento údaj môže byt ale skreslený tým, že práve táto čast’ bola najviac preskúmaná. Po porovnaní objektov s textilnými nástrojmi s objektmi identifikovanými Pavelčíkom ako chaty som spozorovala, že prasleny sa nachádzajú v blízkosti chát. V dvoch prípadoch pochádza objekt chaty a objekt, v ktorom sa našli prasleny a tkáčske závažia z rovnakej sondy. Najhustejšia oblast' výskytu textilných nástrojov na sídlisku tvoria sondy S23/72, S26/73, S27/73, S31/74, S29/73, S24/73 a S9/69, ktoré sú všetky pri sebe v tesnej blízkosti. Takáto koncentrácia znamená, že značná čast’ výroby mohla byt’ sústredená práve v tejto časti hradiska. Nástroje pochádzajú z objektov, ktoré sú takmer rovnako zastúpené a to sú hliníky a pivnice, obe tvoria približne 23 až 24 percent. Sedemnást̉ percent skúmaných textilných nástrojov sa našlo v objektoch prislúchajúcich $\mathrm{k}$ chate, ide len o tri objekty, avšak množstvo nástrojov v nich nájdených je vysoké. V silách sa našlo najmenej zástupcov textilnej výroby.

Do úvahy musíme brat' i fakt, že v mnohých objektoch, roztrúsených po celom sídlisku, sa našli textilné nástroje po jednom alebo maximálne po dvoch, čo súvisí aj s tým, ako bolo spomenuté vyššie - priast' je možné kdekolvek a súčasne pri rôznych aktivitách (napr. stráženie detí, varenie apod.).

To, že sa nenašlo jedno konkrétne miesto, kde by sa koncertovala výroba, poukazuje na stupeň špecializácie na úrovni domácej výroby, pri ktorej pravdepodobne (kvôli vysokému množstvu nástrojov) vznikala nadprodukcia. K tomuto viedli rôzne dôvody, či už technologický vývoj, dopyt po produktoch, nové surové materiály, možná špecializácia sídlisk. Hlinsko svojou polohou patrí medzi hradiská v oblasti Moravskej brány, ktorá bola významnou obchodnou tepnou v praveku aj v stredoveku. Okolie rieky Bečvy lemujú vyššie i nižšie položené sídliská, medzi ktorými mohla prebiehat výmena tovaru (Šebela et al. 2007, 286). Sídliská mohli plnit funkciu distribučných uzlov, na lokalitách Lipník nad Bečvou, Osek nad Bečvou a Předmostí sa našli nálezy štiepanej industrie. V poslednej zmienenej lokalite sa okrem štiepanej industrie zachovala aj skupina praslenov (Šebela et al. 2007, 286-287). Podobný vývoj v období badenskej kultúry, teda siet’ vyššie ako aj nižšie položených menších a väčších sídlisk sledujeme nielen na Morave ale aj v Panónskej nížine (Horváth - Virág 2003, 127), kde vyššie položene sídliská plnia funkciu socioekonomických centier pre menšie osídlenia, ktoré sú roztrúsené v blízkosti riek (Durman 1995; Tasić 2003-2004). Hlinsko, svojou polohou na do- 
pravnej tepne a na vyvýšenom mieste, s množstvom nájdeného materiálu mohlo plnit práve túto funkciu.

\section{Záver}

Vysoký počet praslenov a tkáčskych závaží na hradisku Hlinsko naznačuje intenzifikáciu textilnej výroby, ktorá pravdepodobne prekročila úroveň domácej výroby. Absencia textilných zvyškov z lokality nám neumožňuje presný popis použivaného materiálu, preto musíme rátat hlavne s vláknami rastlinného pôvodu ako lan, lyká stromov, apod. Nepriame dôkazy textilnej výroby poukazujú na zmenu, ktorá prebehla v 4. tisícročí pred naším letopočtom a nutnost’ prispôsobit sa prírodným podmienkam ako i zvyšujúcemu sa dopytu po textile. Medzi hlavné patrí používanie lahkých a vyšších praslenov, ktoré sa krútia rýchlejšie, urobia viac zákrutov a zabezpečia tak lepšie spojenie kratších, živočíšnych vláken. Prispôsobenie rozmerov praslenov $\mathrm{k}$ pradeniu iných typov vláken je jednou z inovácií, ktorá mala vplyv na výsledný produkt. Lahšími praslenmi sa samozrejme mohli priaste aj rastlinné vlákna, v tomto období sa v Európe objavuje nový typ lanu, ktorý je vhodnejší k textilnej produkcii a na lokalitách je doložený menšími semenami. Vo vzorke sa nachádzajú i tažšie prasleny, ktoré slúžili k pradeniu dlhších a hrubších vláken, prípadne k súkaniu. Medzi d’alšie nepriame dôkazy užívania živočíšnych vláken môžeme zaradit zmenu klímy, častejšie výkyvy počasia mohli obmedzit pestovanie niektorých druhov rastlín využívaných v textilnej výrobe, je nutné ale poznamenat, že oblast' Moravy sa nachádza v mieste, kde klimatické výkyvy neboli tak značné ako v iných častiach Európy. Nielen zmena klímy ale aj stále sa zvyšujúci podiel osteologických ostatkov oviec/ kôz v strednom eneolite podporuje používanie živočíšnych vláken. Na sídlisku Hlinsko sa kos- tí oviec/kôz síce našli, avšak vekové rozloženie jedincov bolo rovnomerné, takže sa na základe veku nedá s určitostou tvrdit, či šlo o jedincov chovaných na mäso alebo na vlnu. Je však isté, že v tomto období ešte ovce neboli vyšlachtené natol'ko aby sa chovali len na vlnu, ktorá by svojou kvalitou mohla konkurovat rastlinným vláknam, ako to bolo neskorších obdobiach. K tomuto záveru sa prikláňa i A. Grabundžija, ktorá skúma prasleny v Panónskej a pred Alpskej oblasti a berie nový typ praslenu ako špecifikum badenskej kultúry, ktorá sa šírila strednou Európou (Grabundžija - Russo 2016, Grabundžija 2020, Grabundžija et al. 2021). Tieto znaky síce splňuje i hradisko Hlinsko, avšak k potvrdeniu tohto predpokladu i v strednej Európe obecne je nutné, aby sa preskúmali prasleny z viacerých sídlisk badenskej kultúry.

Tkáčske závažia tvoria menšiu čast̉ nálezového celku textilnej výroby. Kónické závažia sú najčastejším tvarom, všetky študované závažia sa našli v skupinách, dva z nich in situ (Obr. 6) a podla vedúceho výskumu J. Pavelčíka pochádzajú z jedných krosien. $\mathrm{V}$ jednom prípade krosná stáli v blízkosti ohniska, čo je pravdepodobné umiestnenie vzhladom $\mathrm{k}$ potrebe svetla počas tkania. Výpočty spolu s predošlými experimentmi potvrdzujú, že s praslenmi dochovanými na mieste bolo možné upriast̉ nit, ktorá bola následne použitá k tkaniu s danými tkáčskymi závažiami. Priestorová analýza nezachytila žiaden výrobný areál, čo nie je výnimočné, ked’že charakter textilnej výroby si ho ani v danej dobe nevyžadoval oproti iným remeslám. Výroba síce prebiehala v domácom prostredí, ale mala istý stupeň špecializácie, čo dokazuje vel'ké množstvo praslenov a závaží rovnakých rozmerov na jednom mieste. Hlinsko ako hradisko v rámci siete sídlisk v priestore Moravskej brány, plnilo funkciu socioekonomického centra, teda mohlo dochádzat k výmene (a tým $\mathrm{k}$ istej nadprodukcii) remeselných výrobkov medzi ním a nižšie položenými sídliskami. 


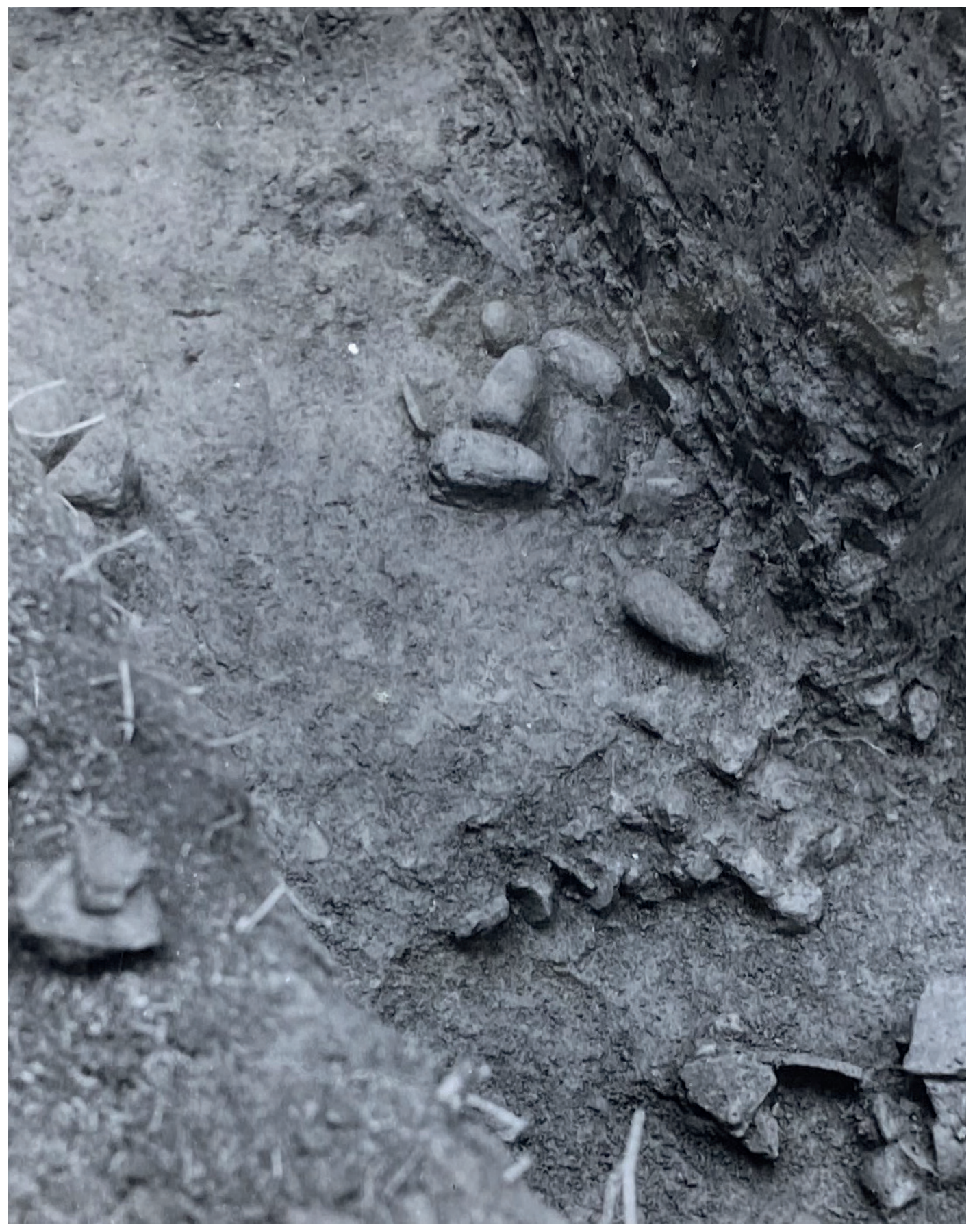

Obr. 6. Fotografia tkáčskych závaží in situ z objektu 15 z roku 1981. (foto z Pavelčík 1982, 176).

Fig. 6. Loom weight in situ in feature 15 excavated in the year 1981. (photo in Pavelčík 1982, 176). 
Tento článok bol vydaný s finančnou podporou grantu poskytnutého GA UK č. 899518, s názvom Textilná výroba strednej Európy v staršom praveku a jej porovnanie s egejskou oblastou, riešeného na Filozofické fakulte Univerzity Karlovej. Chcela by som pod’akovat Múzeu Komenského v Přerove za možnost študovat materiál a nálezové správy, ako aj Mgr. Alešovi Drechslerovi za pomoc pri jeho spracovaní. Za pripomienky by som chcela pod’akovat Mgr. Tereze Štolcovej, Ph.D a doc. Petrovi Pavúkovi, Ph.D.

1) Nálezové správy boli poskytnuté $\mathrm{k}$ nahliadnutiu v Múzeu Komenského v Přerově, ktorému by som sa na tomto mieste chcela pod’akovat za sprístupnenie materiálu a literatúry. Študované nálezové správy z rokov: 1962, 1968, 1969, 1972, 1973, 1974, 1975, 1976, 1977, 1978, 1979, 1980, 1981, 1982, 1983, 1984, 1985, 1987, 1988, 1990. Pod’akovat by som sa chcela i Mgr. Alešovi Drechslerovi za pomoc a ústretovost pri spracovávaní materiálu v múzeu.

2) K d’alším patrí napr. Anna Medunová-Benešová (Medunová-Benešová 1973, 1981), ktorá vo svojich publikáciách podrobne popisuje prasleny a tkáčske závažia, ktoré doplňuje o ich nákresy. Praslenom sa venoval aj Miroslav Šmíd v knihe Eneolitická hradiska na Prostějovsku (Šmíd - Přichystal 2015), kde rozoberá rôzne typy praslenov a ich dekoráciu. Špecializáciu a organizačnú štruktúru výroby textilu v eneolite popísal aj Vratislav Janák (Janák 2009 - 2010).

3) Súkanie - spojenie dvoch alebo viacerých spradených nití do jednej.

4) https://ctr.hum.ku.dk/

5) V tomto prípade bolo urobených mnoho experimentov, avšak nie je možné pre určitú hrúbku nite určit presné napnutie, preto je tento výpočet len približný, vychádza z experimentov ako aj premisy, že čím hrubšia nit, tým väčšie zataženie potrebuje (Andersson Strand et al. 2011, 22).

6) Za poskytnutie CTR Manual for recording textile tools by som chcela pod'akovat' Karine Grömer.

7) Hmotnost̉ bola dopočítaná na základe časti dochovaného fragmentu, výsledná hmotnost̉ celého predmetu sa rovná dvojnásobku polovice fragmentu apod.

8) V našom prostredí sa používa typológia obsahujúca väčšie množstvo tvarov.

9) Rada by som poznamenala, že niekedy je náročné presne určit daný typ a to hlavne pri rozlišovaní medzi šošovkovitými a bikónickými praslenmi - ide o subjektívny názor.

10 Z ich experimentov uvádzam: pri $4 \mathrm{~g}$ praslene je priemer nite $\leq 0,3 \mathrm{~mm}$ hrubá nit potrebuje cca $10 \mathrm{~g}$ na napnutie; pri $8 \mathrm{~g}$ praslene je priemer nite 0,3-0,4 mm hrubá nit potrebuje cca $15-20 \mathrm{~g}$ na napnutie; pri $18 \mathrm{~g}$ praslene je priemer nite $0,4-0,6 \mathrm{~mm}$ hrubá nit potrebuje cca $25-30 \mathrm{~g}$ na napnutie; pri $44 \mathrm{~g}$ praslene je priemer nite $0,8-1,0 \mathrm{~mm}$ hrubá nit potrebuje cca $40 \mathrm{~g}$ na napnutie.

11 Tu vychádzam z experimentálnych výpočtov Mårtensson et al. 2009.

12 Nálezové správy z rokov: 1976, 1982, 1979, 1981, 1984.

13 Za najstarší nález vlny použitej na textil sa považuje zuholnnatený kus z Clairvaux-les-Lacs vo Švajčiarsku datovaný do cca 2900 p.n.l. (Hundt 1986).

14 Vlna sa v tomto období zbierala alebo trhala.

15 Ejstrud et al. 2011. 


\section{Bibliografia}

Andersson Strand, E. 2003: Tools for Textile Production from Birka and Hedeby. Birka Studies 8. Excavations in the Black Earth 1990-1995. Stockholm.

Andersson Strand, E. - Gebauer Thomsen, L. - Cutler, J. 2011: From tools to textiles, a manual for recording, analysing and interpreting textile tools. Unpublished.

Andersson Strand, E. 2012: The textile chaîne opératoire: using a multidisciplinary approach to textile archaeology with a focus on the Ancient Near East. Paléorient, vol. 38. 1-2, 21-40.

Belanová-Štolcová, T. - Grömer, K. 2009: Loom-weights, Spindles and Textiles - Textile Production in Central Europe from the Bronze Age to the Iron Age. In: E. B. Andersson Strand - M. Gleba - U. Mannering - Ch. Munkholt - M. Ringgard (eds.), North European Symposium for Archaeological Textiles X, 13.-18. 5. 2008 in Copenhagen, Ancient Textiles Series 5, Oxford 2009, 9-20.

Barber, E. J. W. 1991: Prehistoric textiles: the development of cloth in the Neolithic and Bronze Ages with special reference to the Aegean. Princeton.

Burke, B. 2010: From Minos to Midas. Oxford.

Cybulska, M. - Maik, J. 2007: Archaeological textiles - a need of new methods of analysis and reconstruction, Fibres and Textiles in Eastern Europe 18(3), 100-105.

Durman, A. 1995: Psihologija naseljavanja telova, Histria Antiqua 1, 153-158.

Drechsler, A. ND: http://www.prerovmuzeum.cz/zamek-prerov/exponaty/drobne-keramicke-zavazi-z-hlinska-s-pravekym-napisem (navštívené 20. 12. 2020).

Dreslerová, D. 2010: Klima v holocénu a možnosti jeho poznání, Živá archeologie REA 11/2010, 18-21.

Ejstrud, B. - Andresen, S. - Appel, A. - Gjerlevsen, S. Thomsen, B. 2011: From flax to Linen, experiments with flax at the Ribe Viking Centre. Esbjerg.

ELKS, 1995: Encyklopédia l'udovej kultúry I., II. Veda, Vydavatel'stvo Slovenskej Akadémie Vied, Ústav etnológie Slovenskej Akadémie Vied, Bratislava.

Evershed, R. P. et al. 2008: Earliest date for milk use in the Near East and southeastern Europe linked to cattle herding, Nature 455, 528-531.
Fu, Y. B. - Allaby, R. G. 2010: Phylogenetic network of Linum species as revealed by non-coding chloroplast DNA sequences.Genetic Resources and Crop Evolution 57, 667-677.

Gleba, M. 2008: Textile Production in Pre-Roman Italy. Oxford.

Gleba, M. - Harris, S. 2019: The first plant bast fibre technology: identifying splicing in archaeological textiles. Archaeological and Anthropological Sciences 11, 2329-46. https://doi.org/10.1007/ s 12520-018-0677-

Grabundžija, A. - Russo, E. 2016: Tools tell tales - climate trends changing threads in the prehistoric Pannonian Plain, Documenta Praehistorica XLIII, 301-326.

Grabundžija, A. 2018: Two sides of a whorl: unspinning meanings and functionality of Eneolithic textile tools. In M. Siennicka - L. Rahmstorf - A. Ulanowska (ed.), First textiles: the beginnings of textile manufacture in Europe and the Mediterranean (Ancient Textiles Series 32), Oxford 129-42.

Grabundžija, A. 2020: Archaeological Evidence for Early Wool Exploitation in South East and Central Europe. Dissertation. Berlin.

Grabundžija, A. - Schlichtherle, H. - Leuzinger, U. - Schier, W. - Karg, S. 2021: The interaction of distant technologies: bridging Central Europe using a techno-typological comparison of spindle whorls, Antiquity 1-21. doi:10.15184/aqy.2021.6

Grömer, K. 2005: Efficiency and technique - experiments with original spindle whorls (Leistung und Technik - Experimente zum Spinnen mit Originalspinwirteln). In: P. Bichler - K. Grömer -R. Hofmann-de Keijzer - A. Kern - H. Reschreiter (eds.), Hallstatt Textiles, Technical Analysis, Scientific Investigation and Experiment on Iron Age Textiles, BAR International Series 1351, Oxford 107-116.

Grömer, K. 2016: The Art of Prehistoric Textile Making. Vienna.

Helbek, H. 1959: Notes on the evolution and history of Linum. Kuml 1959, 103-129.

Herbig, C. - Maier, U. 2011: Flax for oil or fibre? Morphometric analysis of flax seeds and new aspects of flax cultivation in Late Neolithic wetland settlements in southwest Germany, Vegetation History and Archaeobotany 20(6), 527-533. 
Horváth, L. A. - Virág, Z. M. 2003: History of the Copper Age. In: S. Visy (ed.), Hungarian Archaeology at the Turn of the Millennium, Ministry of National Cultural Heritage, Budapest, 125-127.

Hundt, H.J. 1986: Tissus et sparteries. In: P. Petrequin (Hrsg), Les Sites Littoraux Néolithiques de Clairvaux-Les-Lacs (Jura), I, Problematique générale. L'example de la station III, Paris.

Charvát, P. 2011: On Sheep, Sumerians and the Early State. In: L. Vacín (ed.), Ancient Near Eastern Studies in Memory of Blahoslav Hruška. Dresden, 49-60.

Chmielewski, T. - Gardynsski, L. 2010: New frames of archaeometrical description of spindle whorls: a case study of the late eneolithic spindle-whorls from the 1C site in Grödek, District of Hrubieszów, Poland, Archaeometry 52(5), 869-881.

Janák, V. 2009-2010: K rozvoji textilnictví ve starším a středním eneolitu Horního Slezska. Sborník prací Filozofické fakulty brněnské univerzity M 14-15, 2009-2010.

Karg, S. - Diederichsen, A.- Jeppson, S. 2018: Discussing flax domestication in Europe using biometric measurements on recent and archaeological flaxseeds - a pilot study. In: M. siennicka - L. Rahmstorf - A. Ulanowska (eds.), First Textiles. Proceedings of the EAA Session Held in Istanbul (2014) and the First Textiles Conference in Copenhagen (2015), Oxford 31-38.

Kolár̆, J. - Dobisíková, M. - Dreslerová, G. - Drozdová, E. - Fojtová, M. - Hložek, M. - Gregerová, M. Přichystal, A. - Urbanová, K. - Wagenknechtová, M. 2011: Kultura se šňůrovou keramikou v povodí ř́ččky Hané na střední Moravě : pohřební areály z prostoru dálnice D1 v úseku Vyškov Mořice a dalších staveb. Pravěk. Supplementu č. 23. Brno.

Kyselý, R. 2012: Paleoekonomika lengyelského období a eneolitu Čech a Moravy z pohledu archeozoologie, Památky archeologické 103, 5-70.

Lüning, J. - Jockenhövel, A. - Bender, H. - Capelle, T. 1997: Deutsche Agrargeschichte. Vor- und Frühgeschichte. Stuttgart.

Maier, U. - Schlichtherle, H. 2011: Flax cultivation and textile production in Neolithic wetland settlements on Lake Constance and in Upper Swabia (south-west Germany). Vegetation History and Archaeobotany 20.6, 567-578.

Mårtensson, L. - Nosch, M.-L. - Andersson Strand, E. 2009: Shape of Things: Understanding a Loom Weight, Oxford Journal of Archaeology 28(4), 373-398.

Medunová-Benešová, A. 1981: Jevišovice - Starý Zámek: Schicht C2, C1, C : Katalog der Funde. Brno.

Medunová-Beněsová, A. 1973: Grešlové Mýto. Aneolith. Höhensiedlung " Nad Mirovcem », Kat.der Funde. Brno.

Nývltová-Fišáková, M. - Kratochvíl, Z. 2007: Kosterní pozůstatky divokých a domácích zvířat. In: Šebela, L. et al. (ed.): Hlinsko - výšinná osada badenské kultury. Spisy Archeologického ústavu AV C̆R Brno 32, 263-270.

Pavelčik, J. - Pavelčrk, J. - Lohniský, K. - Lanting, A. - Quitta, H. 1975: Hlinsko. Nálezová zpráva. Výzkumná sezóna, r. 1974.

Pavelčik, J. - Kratochvíl, Z. 1982: Hlinsko. Nálezová zpráva. Výzkumná sezóna, r. 1981.

Pavelčik, J. 1983: Drobné terakoty z Hlinska u Lipníku (okr. Přerov) II, Památky archeologické 74/2, 295-315.

Rast-Eicher, A. 2005: Bast before wool. In: P. Bichler et al. (eds.), Hallstatt Textiles - Technical Analysis, Scientific Investigation and Experiment on Iron Age Textiles. BAR - British Archaeological Reports, International Series 1351, Oxford 117-135. Ryder, M. L. 1983: Sheep and Men. London.

Sherratt, A. G. 1981: Plough and pastoralism: aspects of the secondary products revolution. In: I. Hodder - G. Isaac - N. Hammond (eds.), Pattern of the Past: Studies in honour of David Clarke, Cambridge 261-305.

Staničová, J. 2017: Textilná produkcia v strednej a neskorej dobe bronzovej na gréckej pevnine a v západnej Anatólii. Diplomoví práca. Praha.

Staničová, J. 2019: Prehistoric spindle whorls from Central Europe. Poster at VII International Symposium Purpureae Vestes. Granada.

Šebela, L. et al. 2007: Hlinsko: výšinná osada lidu badenské kultury. Spisy archeologického ústavu AV ČR 32, Brno.

Šmid, M. 2003: Mohylová pohřebiště kultury nálevkovitých pohárů na Moravě. Ústav archeologické památkové péče. Brno. 
Šmíd, M. - Přichystal, A. 2015: Eneolitická hradiska na Prostějovsku. Ohrozim - Čubernice a Prostějov-Čechovice - Čechovsko. Brno.

Tasic, N. 2003-2004: Historical picture of development of Bronze Age cultures in Vojvodina, Starinar 53-54, 23-34.
Vila, E. - Helmer, D. 2014: The Expansion of Sheep Herding and the Development of Wool Production in the Ancient Near East: An Archaeozoological and Iconographical Approach. In: C. Breniquet - C. Michel (eds.), Wool Economy in the Ancient Near East and the Aegean, Ancient Textile Series vol. 17, Oxford 22-40. 


\section{Analysis of spindle whorls and loom weights from Hlinsko-Nad Zbružovým}

The site Hlinsko is exceptional for the high number of excavated tools connected with textile production. The tools were examined by Jiří Pavelčík (Pavelčík 1983). In the eighties of the last century, objects connected with the textile production were described, their functionality was not analysed based on weight and dimensions. This article complements the individual data and determines the type of the resulting thread, fabric as well as the possibility of specialization. After careful consideration, I decided to analyse the tools from Hlinsko, not all that were available, but selected individual pieces recovered in groups, to bring the greatest informative value, whether about the type of thread or properties of the fabric. All the data are collected in the SQL database.

Two hundred thirty-eight spindle whorls were analysed, due to the state of preservation 19 were omitted in the weight/diameter analysis. From Graph 1 we can conclude the most popular type is conical and lenticular, the weight is mostly between $20-40 \mathrm{~g}$. The type of spindle whorls does not determine weight range (Graph 2). The weight of spindle whorls points to the spinning of thinner yarn, but it should be highlighted that there are also other variables to influence the final product, mainly the skills of the spinner. Loom weights have a conical shape, their weight is often very similar within the groups. We cannot tell if the loom weights recovered together are from one loom, except from two cases when Pavelčík in excavation reports consider loom weights to be from one loom (Pavelčik - Kratochvil 1982, 75; Pavelčik et al. 1975). Based on the weight and thickness of the loom weight I tried to find the possible set up of the loom and to describe the final fabric as the weight of a loom weight defines what yarn to use and the thread density. The thickness of a loom weight, and thus the width of the row of loom weights hanging closely together, defines the width of a fabric and together with the weight of the loom weight - the thread count and density of the fabric (Martenson et al. 2009, 373). As no actual textile was recovered on the site, the warp tension per thread was calculated from the experiments Mårtenson et al. 2009. We can conclude that the optimal tension per warp thread is $30 \mathrm{~g}$ and $40 \mathrm{~g}$ for the heavier loom weights (637 $\mathrm{g})$, warp tension of $20 \mathrm{~g}$ per thread and lower is not optimal as weaving with more than 30 threads in not practical. For the lighter loom weights (389 g) the optimal tension per warp thread is $30 \mathrm{~g}$.

The material used for textile production was of vegetable origin, there is no direct evidence of wool from this period. The increasing number of spindle whorls in the archaeological material, the morphological change of spindle whorls that are more suitable for spinning shorter animal fibres and the rise of osteological material of sheep and goats on the Aeneolithic sites, all these signs indicate additional use animal fibres. The fact that people were looking for new and faster ways of obtaining and processing fibres is also evidenced by the cultivation of a new type of flax in the middle of the 4th millennium BC in Europe, which was more suitable for textile production (Maier - Schlichtherle 2011; Karg - Diederichsen-Jeppson 2018).

The production of textiles took place in the domestic environment, the district only to produce textiles was not confirmed on the site, which is not exceptional, as spinning can be conducted during other activities. The high number of spindle whorls of the same size and weight in one place indicates that threads of the same quality were spun. Hlinsko belonged to the higher laying settlements in the Moravian gate area and was a socio-economic centre, so exchange of goods between Hlinsko and the lower settlements was probable (Šebela et al. 2007, 286). We observe a similar development in terms of the dimensions of spindle whorls (Grabundžija Russo 2016) as well as the network of higher and lower settlements (Horváth - Virág 2003, 127) in the Pannonian Plain. 


\section{Mgr. Jana Šofránková}

- Filozofická fakulta Univerzity Karlovy Radimova 136/27, Praha 169 00, CZ

janastanicova@gmail.com 